\title{
Expression and Function of ABC Proteins in Fish Intestine
}

\author{
Flavia Bieczynski ${ }^{1}$, Julio C. Painefilú2 ${ }^{2}$ Andrés Venturino ${ }^{1}$ and Carlos M. Luquet ${ }^{3 *}$ \\ ${ }^{1}$ Centro de Investigaciones en Toxicología Ambiental y Agrobiotecnología del Comahue - Consejo Nacional \\ de Investigaciones Científicas y Técnicas, Universidad Nacional del Comahue, Neuquén, Argentina, ${ }^{2}$ Instituto Patagónico \\ de Tecnologías Biológicas y Geoambientales, Consejo Nacional de Investigaciones Científicas y Técnicas - Universidad \\ Nacional del Comahue, Bariloche, Argentina, ${ }^{3}$ Laboratorio de Ecotoxicología Acuática, Subsede INIBIOMA-CEAN \\ (CONICET - UNCo), Junín de los Andes, Argentina
}

In fish, the intestine is fundamental for digestion, nutrient absorption, and other functions like osmoregulation, acid-base balance, and excretion of some metabolic products. These functions require a large exchange surface area, which, in turn, favors the absorption of natural and anthropogenic foreign substances (xenobiotics) either dissolved in water or contained in the food. According to their chemical nature, nutrients, ions, and water may cross the intestine epithelium cells' apical and basolateral membranes by passive diffusion or through a wide array of transport proteins and also through endocytosis and exocytosis. In the same way, xenobiotics can cross this

OPEN ACCESS

Edited by:

Maria Giulia Lionetto,

University of Salento, Italy

Reviewed by:

Amilcare Barca,

University of Salento, Italy

Enrrico Bloise

Federal University of Minas Gerais,

Brazi

${ }^{*}$ Correspondence:

Carlos M. Luquet

luquetc@comahue-conicet.gob.ar

Specialty section:

This article was submitted to

Aquatic Physiology,

a section of the journal

Frontiers in Physiology

Received: 09 October 2021 Accepted: 17 November 2021 Published: 09 December 2021

Citation:

Bieczynski F, Painefilú JC, Venturino $A$ and Luquet CM (2021) Expression and Function of $A B C$

Proteins in Fish Intestine.

Front. Physiol. 12:791834. doi: 10.3389/fphys.2021.791834 barrier by passive diffusion or taking advantage of proteins that transport physiological substrates. The entry of toxic substances is counterbalanced by an active efflux transport mediated by diverse membrane proteins, including the ATP binding cassette (ABC) proteins. Recent advances in structure, molecular properties, and functional studies have shed light on the importance of these proteins in cellular and organismal homeostasis. There is abundant literature on mammalian ABC proteins, while the studies on $\mathrm{ABC}$ functions in fish have mainly focused on the liver and, to a minor degree, on the kidney and other organs. Despite their critical importance in normal physiology and as a barrier to prevent xenobiotics incorporation, fish intestine's ABC transporters have received much less attention. All the $A B C$ subfamilies are present in the fish intestine, although their functionality is still scarcely studied. For example, there are few studies of ABC-mediated transport made with polarized intestinal preparations. Thus, only a few works discriminate apical from basolateral transport activity. We briefly describe the main functions of each $A B C$ subfamily reported for mammals and other fish organs to help understand their roles in the fish intestine. Our study considers immunohistochemical, histological, biochemical, molecular, physiological, and toxicological aspects of fish intestinal $A B C$ proteins. We focus on the most extensively studied fish $A B C$ proteins (subfamilies $A B C B, A B C C$, and $A B C G$ ), considering their apical or basolateral location and distribution along the intestine. We also discuss the implication of fish intestinal $\mathrm{ABC}$ proteins in the transport of physiological substrates and aquatic pollutants, such as pesticides, cyanotoxins, metals, hydrocarbons, and pharmaceutical products.

Keywords: multixenobiotic resistance, epithelial physiology, aquatic pollutants, polarized transport, detoxification 


\section{INTRODUCTION}

Aquatic animals take up food and water together; therefore, their digestive systems are exposed to xenobiotics present in the food or dissolved in water. This risk is particularly enhanced in marine teleost fish, which drink high volumes of water for osmoregulation purposes. The intestinal epithelium (mucosa) is the main surface of alkaline digestion and nutrient absorption and reabsorption of bile acids. These functions require a large surface area of epithelial tissue with a broad spectrum of inwardly directed membrane transporters. Additionally, in marine teleosts, the intestinal mucosa participates in osmoregulation and ionic and acid-base balance. Thus, the intestinal mucosa offers a large surface area for the entry of xenobiotics, either through simple diffusion or facilitated by a great diversity of proteins that primarily transport nutrients, bile acids, ions, or water. The biotransformation and active excretion of xenobiotics at the luminal membrane of the intestine mucosa limits their incorporation. Alternatively, the parent or biotransformed substance is transported by the blood to the liver and the kidney to be metabolized and excreted (Wang and Wang, 2016).

The efflux of xenobiotics and their conjugates from the cells occurs through diverse membrane transporters such as the ATP-binding cassette (ABC) proteins. This function confers the multidrug resistance (MDR), formerly described for chemotherapy-resistant cancer cells (Roninson et al., 1984; Gros et al., 1986), and the multixenobiotic resistance (MXR), defined by Kurelec (1992) for aquatic animals. As well as in mammals, the physiological roles of fish ABC proteins have been extensively studied in liver and kidney tissues (see reviews by Bard, 2000; Sturm and Segner, 2005; Ferreira et al., 2014; Luckenbach et al., 2014). In contrast, the studies on fish intestinal ABC proteins are still scarce and have not been reviewed so far.

This work summarizes physiological, molecular, immunochemical, and toxicological information on fish intestinal $\mathrm{ABC}$ proteins. We aim to update and integrate the current knowledge on fish intestinal $\mathrm{ABC}$ proteins concerning the organ's physiology and responses to environmental threats.

\section{THE GASTROINTESTINAL SYSTEM OF FISH}

Fish are classified into three groups: Agnatha (jawless fishes: hagfish and lampreys), Chondrichthyes (cartilaginous fishes), and Osteichthyes (bony fishes), among which Teleostei is the most abundant and diverse group (Betancur et al., 2017; Mikalsen et al., 2021). Most studies on ABC proteins focus on teleosts and chondrichthyans and lampreys to a lesser extent.

The fish GI consists of four regions: the headgut (the mouth and pharynx), foregut (the esophagus and stomach, where chemical digestion begins), midgut (the intestine, which completes chemical digestion and most of the absorption), and hindgut (the posterior region, including the rectum) (Wilson and Castro, 2011). The anatomy of fish intestines varies among species, and different authors describe it with different terminologies. For example, some authors use the term "gut" to
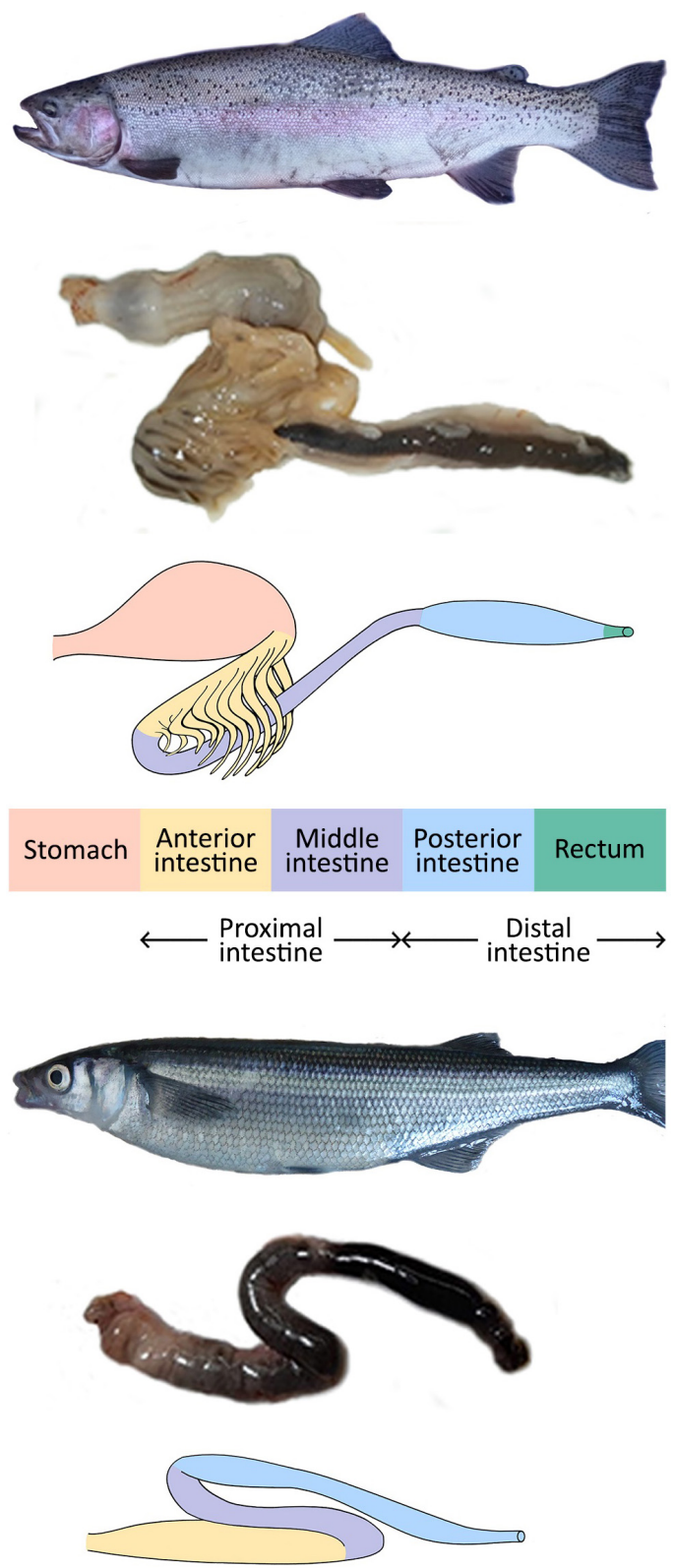
Anterior
intestine
Middle
intestine
Posterior intestine

FIGURE 1 | Rainbow trout (Oncorhynchus mykiss) and Patagonian silverside (Odontesthes hatcheri) (top and bottom, respectively) with a detail of their gastrointestinal tracts.

refer to the GI, while others use it as a synonym of the intestine, making it difficult to compare studies. This review will refer to the intestine and its parts only with "intestine" (Figure 1).

The limit between intestinal portions is not always externally visible. However, histological features related to specific intestinal functions allow their identification (Grosell et al., 2011; Brugman, 2016). Lampreys, chondrosteans, chondrichtheans, and dipnoids 
have short intestines with the mucosa and submucosa folded to form a spiral valve, which increases the absorption surface area and delays the food passage. In addition, mucosal folds increase the surface area of the spiral folds (Wetherbee and Cortés, 2004; Wilson and Castro, 2011). At the distal end of the GI, chondrichtheans possess a salt-secreting structure, the rectal gland.

The stomach is present in most jawed vertebrates, including bony fishes. However, some teleosts have lost this structure and the genes encoding $\mathrm{H}^{+} / \mathrm{K}^{+}$-ATPase and pepsinogens (Koelz, 1992; Castro et al., 2013). In agastric fish, such as the zebrafish (Danio rerio), the intestine consists of an anterior portion or intestinal bulb, middle, and posterior intestine. The intestinal bulb has an enlarged lumen but lacks gastric glands and pylorus, and its $\mathrm{pH}$ is not lower than 7.5 (Brugman, 2016 for a review). In the anterior and middle portions, the presence of folds, digestive enzymes, and the expression of genes involved in lipid metabolism and solute transport indicate digestive and nutrient absorption functions. The posterior intestine mucosa has short folds and mediates water absorption (Brugman, 2016 for a review). Figure 1 shows a scheme of the GI of an omnivorous agastric fish, the Patagonian silverside, Odontesthes hatcheri (Bieczynski et al., 2016).

Most carnivorous fish, e.g., salmonids, possess a stomach with acid digestion enzymes. Their intestine consists of two portions, the anterior, which often bears numerous pyloric ceca that increase the surface area for digestion and absorption, and the posterior portion (e.g., Rust, 2003; Verdile et al., 2020). However, other authors (e.g., Kamalam et al., 2020) recognize three segments: the anterior with the pyloric ceca; the middle and posterior portions, which end in the rectum (Figure 1).

\section{ABC PROTEINS}

The general characteristics, structure, function, substrates, and regulation of the proteins of the $\mathrm{ABC}$ superfamily are extensively described in the literature (e.g., Holland et al., 2003; Chan et al., 2004; Stolarczyk et al., 2011; Luckenbach et al., 2014; Thomas et al., 2020 for reviews). All these proteins have a highly conserved nucleotide-binding domain, NBD (or ATP binding cassette, ABC), which catalyzes the hydrolysis of ATP, coupling the energy released in this reaction to other cellular functions such as molecule transport. Their basic structure consists of a hydrophobic integral membrane domain (IM), also called transmembrane domain (TMD), and a hydrophilic cytoplasmic region, the NBD. The full transporters from this superfamily are composed of four structural domains, two IMs and two NBDs, while half transporters possess one of each domain.

According to their function, ABC proteins can be importers, exporters, or proteins with other roles such as DNA repair. Most eukaryotic $\mathrm{ABC}$ proteins are active exporters. In this context, exportation means transporting a molecule from the cytosol into another compartment, either extracellular or intraorganellar (Dassa, 2003). There are seven mammalian ABC subfamilies (ABCA-G) (Dean et al., 2001), two subfamilies identified in non-mammalian organisms $(\mathrm{ABCH}$ in insects and fish; $\mathrm{ABCI}$ in plants), and ABCJ, a new subfamily suggested for the mosquito Aedes aegypti (Verrier et al., 2008; Figueira-Mansur et al., 2020).

This review follows the Zebrafish Nomenclature Guidelines for the $\mathrm{ABC}$ gene and protein designation (ZFIN Zebrafish Nomenclature Conventions, 2019). For example, for zebrafish gene/protein: abcc/Abcc, and ABCC/ABCC for humans. Finally, we use capital letters to refer to $\mathrm{ABC}$ proteins in general or ABC subfamilies.

\section{Physiological Role of ABC Proteins}

The phylogenetic relation of $\mathrm{ABC}$ genes shows the conservation of critical functions among species and some species- or lineagespecific functions (Annilo et al., 2006). There is a vast literature about the $\mathrm{ABC}$ functionality in humans and mammalian models because many human diseases are related to ABC failures (Dean et al., 2001). In fish and other organisms, there is still little knowledge on this subject. This section introduces the known physiological functions of each $\mathrm{ABC}$ protein in mammals and compares them with the available information on fish $\mathrm{ABC}$ proteins.

\section{ABCA}

This subfamily is related to cholesterol and lipid transport (Klaassen and Aleksunes, 2010; Hedditch et al., 2014; Szakacs and Abele, 2020). ABCA1 participates in the efflux to the plasma and maturation of cholesterol high-density lipoproteins (HDL) and transports other lipids and oxysterols (Venkateswaran et al., 2000; Brunham et al., 2006; Tam et al., 2006). ABCA2 is present in lysosome-related organelles, and its expression correlates with genes involved in cholesterol homeostasis (Szakacs and Abele, 2020). ABCA3 takes part in the regulation of pulmonary surfactants (Szakacs and Abele, 2020; Wambach et al., 2020). ABCA4 transports retinoid-lipid complexes (Cremers et al., 2020), and ABCA5 and ABCA7 regulate the amyloid-beta peptide production and transport (Fu et al., 2015; Aikawa et al., 2018).

Fish Abcal is critical for assembling the HDL by transporting cholesterol from the cell to lipid-poor apoA-I. Its defect is responsible for aberrant angiogenesis in zebrafish (Fang et al., 2013, 2014 for a review). Kortner et al. (2014) have detected Abcal in the pyloric caeca of the Atlantic salmon (Salmo salar), and Liu et al. (2016) report the RNA expression of abcal and abca 2 in the common carp intestine.

\section{$\mathrm{ABCB}$}

The most studied ABC protein, ABCB1 (MDR1, Pgp), transports lipophilic compounds such as steroid hormones, and is related to toxic metabolites and xenobiotic efflux from the cytosol and is essential in the MDR phenotype (Gottesman et al., 1996; Chan et al., 2004). ABCB1, together with ABCC2 and ABCG2, has apical localization in polarized cells, forming a defense barrier against toxic compounds and therapeutic drugs. ABCB2 and ABCB3 (also named TAP1 and TAP2) are associated with antigen processing (Hinz and Tampé, 2012); ABCB4 (MDR2/3) is also apically located and transports phosphatidylcholine into the bile and also some drugs with similar substrate affinity as that of ABCB1 (Chan et al., 2004; Borst, 2020). ABCB5 is a marker of 
dermal cells with immunoregulatory functions (Schatton et al., 2015) and could be involved in melanogenesis (Chen et al., 2005). ABCB6 and ABCB7 are mitochondrial proteins; the former is a porphyrin transporter and takes part in the cellular defense against cadmium and arsenic (Boswell-Casteel et al., 2017; Wachnowsky et al., 2018; Rakvács et al., 2019). ABCB10 is a mitochondrial transporter related to hemoglobinization (Seguin et al., 2017). ABCB11, also called bile salt export pump (BSEP) or sister $P$-glycoprotein (Spgp), is apically located in hepatocytes and enterocytes and is critical for bile secretion. Its mutation is associated with cholestasis (Nayagam et al., 2020).

Abcb1 (Pgp) is also one of the most studied ABC proteins in fish and aquatic invertebrates. Fischer et al. (2013) have shown that, in zebrafish, two genes coding for apical membrane proteins with Pgp characteristics formerly recognized by Annilo et al. (2006) as abcbla and abcblb correspond to abcb5 and abcb4, and that abcb4 is the functional homolog of human ABCB1 in this species. Later studies show similar results for other fish species (see section “ABCB” for details). Like mammalian $\mathrm{ABCB} 1$ proteins, fish Abcb4 plays an essential role in extruding toxic compounds as a part of the MXR system (Kurelec, 1992; Bard, 2000; Sturm and Segner, 2005; Luckenbach et al., 2014 for reviews). Fish Abcb5 has a different function than the mammalian protein. It is another apical solute transporter related to xenobiotic efflux (Kropf et al., 2020; Robey et al., 2021). The zebrafish bile acid cyprinol sulfate induces the transcription of abcb5 in zebrafish liver (Reschly et al., 2007), suggesting potential roles of Abcb5 related to biliary excretion. Zebrafish Abcb3 and Abcb7 are mitochondrial transporters involved in heavy metal detoxification (Lerebours et al., 2016). Abcb7 participates in iron and fatty acid metabolism (Miyake et al., 2008). Abcb10, a mitochondrial $\mathrm{ABC}$ transporter associated with the response to oxidative stress, was detected in zebrafish muscle brain, gill, and intestine (Sabri et al., 2012). Like its mammalian counterparts, fish Abcb11 has an essential role in bile secretion (Ellis et al., 2018).

\section{ABCC}

This is a large subfamily that includes full transporters with diverse functions like ion transport, cell surface receptors, and detoxification of toxic compounds. In mammals, ABCC1 to 5 (MRP1-5) pump a structurally diverse array of endogenous substrates (leukotrienes, estrogen conjugates, bile salts, bilirubin, estradiol-17, organic anions, folic acid, cyclic nucleotides, among others) and xenobiotics out of the cells (Chan et al., 2004; He et al., 2011; Slot et al., 2011 for review). Among these proteins, only ABCC2 is apical, while the others are basolateral in all tissues, except ABCC4, which is apical in the kidney (Van Aubel et al., 2002; De Waart et al., 2012). ABCC6 exports nucleoside triphosphates, mainly ATP, from the hepatocytes to the bloodstream, and this activity is essential for a normal mineralization process (Szeri et al., 2021). It is also involved in the efflux of natural toxins and drugs (Chan et al., 2004). ABCC7 (cystic fibrosis transmembrane conductance regulator, CFTR) is an ATP-sensitive chloride channel mutated in patients with cystic fibrosis (Meng et al., 2018). ABCC8 and ABCC9 (SUR1 and SUR2) are sulfonylurea receptors; ABCC8 forms part of the structure of the ATP-sensitive potassium channel (KATP). ABCC10, ABCC11, and ABCC12 have been less studied, although they seem to be involved in drugs and endogenous compounds transport (Chan et al., 2004; Kruh et al., 2007).

In fish, the studies about the $\mathrm{ABCC}$ protective function against toxic substances concern mostly Abcc1 and Abcc2 but also Abcc3 to 5 (Klobučar et al., 2010; Cárcamo et al., 2011; Long et al., 2011a,b; Bieczynski et al., 2014, 2016; Painefilú et al., 2019, 2020; Lu et al., 2021; among others). Abcc6 is involved in the regulation of tissue calcification, e.g., scales mineralization (Parreira et al., 2018; Sun et al., 2021). Interestingly, this gene is present in bony vertebrates but not in elasmobranches, agnathans, or invertebrates (Parreira et al., 2018). The chloride channel Abcc7 has ionic and osmotic regulation functions in elasmobranches and bony fishes (Evans, 2010; Forrest, 2016 for reviews). Zebrafish abcc 8 and abcc9 correspond to mammalian SUR1 and SUR2. Abcc8 is also part of ATP-sensitive potassium channels (KATP) (Zhang et al., 2006). The RNA expression of abcc9 is associated with cardioprotective sarcolemmal KATP currents in hypoxic fish (Cameron et al., 2013).

\section{ABCD}

These transporters are present in the peroxisomal (ABCD1, $\mathrm{ABCD} 2$, and $\mathrm{ABCD} 3$ ) and the endoplasmic reticulum and lysosomal (ABCD4) membranes (Tawbeh et al., 2021 for a review). Mammalian $\mathrm{ABCD} 1$ and $\mathrm{ABCD} 2$ export long- and very-long-chain fatty acids (VLCFA) or their CoA-derivatives into peroxisomes. $\mathrm{ABCD} 3$ participates in transporting branchedchain acyl-CoA into peroxisomes, while ABCD4 is related to vitamin B12 translocation from lysosomes to the cytosol (Baker et al., 2015). In humans, genetic defects of ABCD1 and ABCD3 are associated with two genetic disorders, the X-linked adrenoleukodystrophy (ALD) and the congenital bile acid synthesis defect 5, respectively (Tawbeh et al., 2021 for a review).

In zebrafish, abcd1 mutant individuals show elevated VLCFA levels, similar to human patients with ALD (Strachan et al., 2017). In turn, abcd 4 knockdown zebrafish develop vitamin B12deficiency anemia (Choi et al., 2019).

\section{ABCE-F}

These proteins are related to ribosome metabolism and are essential in the translation process. In most genomes, this subfamily only includes ABCE1, although two paralogs (abce1 and abce2) exist in some plant, fish, and mosquito species (Navarro-Quiles et al., 2018 for a review). A non-functional abce1 is associated with lethal and slow growth phenotypes in zebrafish embryos (Amsterdam et al., 2004; Navarro-Quiles et al., 2018 for a review). Similarly, ABCF members are associated with ribosome assembly or protein translation (Annilo et al., 2006). However, as far as we know, there are no functional studies on these proteins in fish.

\section{ABCG}

These proteins are involved in the transport of lipids and sterols, maintaining lipid homeostasis in cells, as well as in xenobiotic defense (Kerr et al., 2021 for a review). There are five ABCG-transporters (ABCG1, ABCG2, ABCG4, ABCG5, 
and ABCG8) in humans. ABCG1 exports cholesterol through the basolateral membrane to phospholipid-rich nascent HDL particles, oxysterols, and cholesterol synthesis intermediates in various cell types. In addition, ABCG1 plays a role in regulating inflammation, and it participates in lipid storage and exportation out of adipocytes. The breast cancer resistance protein (ABCG2BCRP) is expressed in "barrier" sites, e.g., the apical membrane of enterocytes, and is related to limiting the uptake of drugs and xenobiotics into the bloodstream. Also, it is involved in the non-renal clearance of uric acid and the transport of endogenous substrates such as conjugated steroid hormones. ABCG4 is involved in the transport of cholesterol, oxysterols, and cholesterol-synthesis intermediates. ABCG5 and ABCG8 mediate the intestinal and biliary efflux of neutral sterols, such as cholesterol, plant sterols, and shellfish defense sterols. These proteins are half-transporters that become functional by forming a heterodimer that translocates to the apical membrane (Graf et al., 2003; Kerr et al., 2021 for a review).

Reports on fish Abcg1 are available only for zebrafish lipid metabolism and related human diseases (atherosclerosis and angiogenesis) (Fang et al., 2013, 2014 for a review). Abcg2 is the most studied member of this subfamily in fish as an essential protein concerning xenobiotics detoxification (Paetzold et al., 2009; Kropf et al., 2016; Zaja et al., 2016, among others). (Zhang L. et al., 2020) characterized zebrafish abcg5 and abcg8. The proteins codified by these genes are present in zebrafish embryos and adult individuals (mainly in the liver and intestine). These authors report that the products of zebrafish abcg5 and abcg8 transfected in a cell system localize to the cell membrane only when both genes are co-expressed. A study by Zhu et al. (2018) shows that rainbow trout (Oncorhynchus mykiss) fed with a plant-based diet (poor in cholesterol) suffer abcg8 (among other genes) down-regulation, probably as a mechanism to maintain cholesterol homeostasis.

\section{$\mathrm{ABCH}$}

This subfamily was first identified in the Drosophila melanogaster genome and is present in the sea urchin and in all the arthropod genomes sequenced up to know, but not in fungi, plants, or mammals (Annilo et al., 2006; Sturm et al., 2009; Popovic et al., 2010; Dermauw and Van Leeuwen, 2014). Among fish, the abch gene appears only in the zebrafish and in the green spotted pufferfish (Tetraodon nigroviridis) (Luckenbach et al., 2014).

\section{ABC PROTEINS IN FISH}

\section{Whole-Genome Analyses}

The superclass Agnatha is represented now by lampreys and hagfishes. Ren et al. (2015) identified 37 ABC genes: seven abca, ten $a b c b$, ten abcc, three abcd, one abce, three abcf, and three abcg, in a genome-wide ABC gene survey in the sea lamprey (Petromyzon marinus) and the Japanese lamprey (Lethenteron japonicum). Besides, by high throughput RNA sequencing in tissues from different developmental stages, these authors recorded a strong expression of abce and abcf genes plus the $\mathrm{abcb} 7$ and abcc5 genes in all or most analyzed tissues. Particularly
TABLE 1 | Studies on fish intestine ABC proteins.

\begin{tabular}{|c|c|c|c|}
\hline Species & $A B C$ protein & Methodology & References \\
\hline \multirow[t]{2}{*}{$\begin{array}{l}\text { Anguilla } \\
\text { japonica }\end{array}$} & Abcc7 & $\mathrm{F}$ & $\begin{array}{l}\text { Ando and } \\
\text { Takei, } 2015\end{array}$ \\
\hline & Abcc7 & $\mathrm{IHC}, \mathrm{M}$ & $\begin{array}{l}\text { Wong et al., } \\
2016\end{array}$ \\
\hline Cyprinus carpio & $\mathrm{ABCA}-\mathrm{ABCH}$ & $\mathrm{M}$ & Liu et al., 2016 \\
\hline \multirow[t]{11}{*}{ Danio rerio } & Abcb4 & $\begin{array}{l}\mathrm{B}, \mathrm{F}, \mathrm{M}, \mathrm{T} \\
\text { WISH }\end{array}$ & Lu et al., 2015 \\
\hline & Abcb4; Abcb5 & $\begin{array}{l}\mathrm{F}, \text { IHC, M, MF, } \\
\mathrm{T}, \mathrm{WB}\end{array}$ & $\begin{array}{l}\text { Robey et al., } \\
2021\end{array}$ \\
\hline & Abcc1 to 5 & $\mathrm{M}, \mathrm{F}$ & $\begin{array}{l}\text { Moraes et al., } \\
2020\end{array}$ \\
\hline & Abcc2 & $\begin{array}{l}\mathrm{F}, \mathrm{IHC}, \mathrm{M}, \mathrm{MF} \\
\mathrm{T}, \mathrm{WISH}\end{array}$ & $\begin{array}{l}\text { Long et al., } \\
2011 c\end{array}$ \\
\hline & Abcc4 & $\begin{array}{l}\mathrm{B}, \mathrm{F}, \mathrm{IHC}, \mathrm{M}, \\
\mathrm{MF}, \mathrm{T}, \mathrm{WB}, \\
\text { WISH }\end{array}$ & Lu et al., 2014 \\
\hline & Abcc4 & $\begin{array}{l}\text { B, F, M, T, WB, } \\
\text { WISH }\end{array}$ & Lu et al., 2021 \\
\hline & Abcc5 & $\begin{array}{l}\text { B, M, MF, T, } \\
\text { WISH }\end{array}$ & $\begin{array}{l}\text { Long et al., } \\
2011 \mathrm{a}\end{array}$ \\
\hline & Abcg2 & $M$ & $\begin{array}{l}\text { Kobayashi } \\
\text { et al., } 2008\end{array}$ \\
\hline & Abcg2 & $\mathrm{M}, \mathrm{T}$ & $\begin{array}{l}\text { Zhang Q.L. } \\
\text { et al., } 2020\end{array}$ \\
\hline & Abcg5, Abcg8 & $\begin{array}{l}\mathrm{B}, \mathrm{H} \mathrm{HC}, \mathrm{M}, \mathrm{MF} \\
\mathrm{T}, \mathrm{WB}\end{array}$ & $\begin{array}{l}\text { Zhang L. et al., } \\
2020\end{array}$ \\
\hline & Abch1 & $\mathrm{M}$ & $\begin{array}{l}\text { Popovic et al., } \\
2010\end{array}$ \\
\hline \multirow[t]{3}{*}{$\begin{array}{l}\text { Dicentrarchus } \\
\text { labrax }\end{array}$} & Abcc7 & $\mathrm{HC}, \mathrm{WB}$ & $\begin{array}{l}\text { Bodinier et al., } \\
2009 a\end{array}$ \\
\hline & Abcc7 & $\mathrm{DB}, \| \mathrm{HC}, \mathrm{M}$ & $\begin{array}{l}\text { Bodinier et al., } \\
2009 \mathrm{~b}\end{array}$ \\
\hline & $A b c c 7^{*}$ & $\mathrm{~F}, \mathrm{M}$ & $\begin{array}{l}\text { Alves et al., } \\
2019\end{array}$ \\
\hline \multirow{4}{*}{$\begin{array}{l}\text { Fundulus } \\
\text { heteroclitus }\end{array}$} & Pgp & IHC, M, WB & Cooper, 1996 \\
\hline & Pgp & $\mathrm{IHC}$ & $\begin{array}{l}\text { Bard et al., } \\
2002\end{array}$ \\
\hline & Abcc7 & $\mathrm{F}, \mathrm{M}$ & $\begin{array}{l}\text { Singer et al., } \\
1998\end{array}$ \\
\hline & Abcc7 & $F, \| H C, W B$ & $\begin{array}{l}\text { Marshall et al., } \\
2002\end{array}$ \\
\hline $\begin{array}{l}\text { Gobiocypris } \\
\text { rarus }\end{array}$ & $\begin{array}{l}\text { Pgp, Abcb11, } \\
\text { Abcc1, Abcc2 and } \\
\text { Abcg2 }\end{array}$ & $M$ & $\begin{array}{l}\text { Yuan et al., } \\
2014\end{array}$ \\
\hline \multirow[t]{2}{*}{$\begin{array}{l}\text { Ictalurus } \\
\text { punctatus }\end{array}$} & Pgp & $\mathrm{IHC}, \mathrm{T}$ & $\begin{array}{l}\text { Kleinow et al., } \\
2000\end{array}$ \\
\hline & Pgp & $F, W B$ & Doi et al., 2001 \\
\hline $\begin{array}{l}\text { Lethenteron } \\
\text { japonicum }\end{array}$ & ABCA-ABCG & M & Ren et al., 2015 \\
\hline $\begin{array}{l}\text { Odontesthes } \\
\text { hatcheri }\end{array}$ & $\begin{array}{l}\text { Abcc2, basolateral } \\
\text { ABCCs }\end{array}$ & $\mathrm{B}, \mathrm{F}, \mathrm{T}$ & $\begin{array}{l}\text { Bieczynski } \\
\text { et al., } 2016\end{array}$ \\
\hline \multirow[t]{3}{*}{$\begin{array}{l}\text { Oncorhynchus } \\
\text { mykiss }\end{array}$} & $\begin{array}{l}\text { Abcb4, Abcb11, } \\
\text { Abcc1-5, Abcg2 }\end{array}$ & $M$ & $\begin{array}{l}\text { Lončar et al., } \\
2010\end{array}$ \\
\hline & Abcb4, Abcc1 & $\mathrm{M}, \mathrm{T}$ & $\begin{array}{l}\text { Cárcamo et al., } \\
2011\end{array}$ \\
\hline & Abcb4, Abcb5 & $\mathrm{M}, \mathrm{T}$ & $\begin{array}{l}\text { Love et al., } \\
2021\end{array}$ \\
\hline
\end{tabular}

(Continued) 
TABLE 1 | (Continued)

\begin{tabular}{|c|c|c|c|}
\hline Species & $A B C$ protein & Methodology & References \\
\hline & $\begin{array}{l}\text { Abcc2, basolateral } \\
\text { ABCCs }\end{array}$ & $\mathrm{B}, \mathrm{F}, \mathrm{T}$ & $\begin{array}{l}\text { Bieczynski } \\
\text { et al., } 2014\end{array}$ \\
\hline & $\begin{array}{l}\text { Abcc2, basolateral } \\
\text { ABCCs }\end{array}$ & $\mathrm{B}, \mathrm{F}, \mathrm{M}, \mathrm{T}$ & $\begin{array}{l}\text { Painefilú et al., } \\
2019\end{array}$ \\
\hline & $\begin{array}{l}\text { Abcc2, basolateral } \\
\text { ABCCs }\end{array}$ & $\mathrm{B}, \mathrm{F}, \mathrm{T}$ & $\begin{array}{l}\text { Painefilú et al., } \\
2020\end{array}$ \\
\hline & Abcb4, Abcc2 & $\mathrm{M}, \mathrm{T}$ & $\begin{array}{l}\text { De Anna et al., } \\
2021\end{array}$ \\
\hline \multirow[t]{4}{*}{ Opsanus beta } & Abcc7 & $\mathrm{F}, \mathrm{IHC}, \mathrm{M}$ & $\begin{array}{l}\text { Ruhr et al., } \\
2014\end{array}$ \\
\hline & Abcc7 & $F, M$ & $\begin{array}{l}\text { Ruhr et al., } \\
2015\end{array}$ \\
\hline & Abcc7 & $F, M$ & $\begin{array}{l}\text { Ruhr et al., } \\
2016\end{array}$ \\
\hline & $A b c c 7^{*}$ & F, IHC, WB & $\begin{array}{l}\text { Ruhr et al., } \\
2018\end{array}$ \\
\hline $\begin{array}{l}\text { Oreochromis } \\
\text { mossambicus }\end{array}$ & Abcc7 & $\mathrm{HC}, \mathrm{M}$ & Li et al., 2014 \\
\hline \multirow[t]{2}{*}{$\begin{array}{l}\text { Oreochromis } \\
\text { niloticus }\end{array}$} & $\begin{array}{l}\text { Abcb11, Abcc1, } \\
\text { Abcc2, Abcg2 }\end{array}$ & $\mathrm{M}, \mathrm{T}$ & $\begin{array}{l}\text { Costa et al., } \\
2012\end{array}$ \\
\hline & Pgp & $\mathrm{IHC}, \mathrm{WB}$ & $\begin{array}{l}\text { Costa et al., } \\
2013\end{array}$ \\
\hline \multirow[t]{3}{*}{$\begin{array}{l}\text { Petromyzon } \\
\text { marinus }\end{array}$} & Abcb9 & M & $\begin{array}{l}\text { Uinuk-Ool } \\
\text { et al., } 2003\end{array}$ \\
\hline & $A B C A-A B C G$ & M & Ren et al., 2015 \\
\hline & Abcc7 & $\mathrm{F}, \mathrm{HC}, \mathrm{M}, \mathrm{WB}$ & Cui et al., 2019 \\
\hline $\begin{array}{l}\text { Poecilia } \\
\text { reticulata }\end{array}$ & Pgp & $\mathrm{IHC}$ & $\begin{array}{l}\text { Hemmer et al., } \\
1995\end{array}$ \\
\hline Raja erinacea & Abcc2 & $\mathrm{M}, \mathrm{IHC}, \mathrm{WB}$ & Cai et al., 2003 \\
\hline $\begin{array}{l}\text { Rasbora } \\
\text { sarawakensis }\end{array}$ & $\mathrm{ABCA}-\mathrm{ABCH}$ & M & Lim et al., 2021 \\
\hline Salmo salar & Abca1, Abcg5 & M & $\begin{array}{l}\text { Kortner et al., } \\
2014\end{array}$ \\
\hline $\begin{array}{l}\text { Scophthalmus } \\
\text { maximus }\end{array}$ & Pgp & $\mathrm{M}, \mathrm{WB}$ & $\begin{array}{l}\text { Tutundjian } \\
\text { et al., } 2002\end{array}$ \\
\hline Sparus aurata & $A b c c 7^{*}$ & $\mathrm{~F}, \mathrm{HC}, \mathrm{M}$ & $\begin{array}{l}\text { Gregório et al., } \\
2013\end{array}$ \\
\hline \multirow[t]{9}{*}{$\begin{array}{l}\text { Squalus } \\
\text { acanthias }\end{array}$} & Abcc2 & $\mathrm{F}, \mathrm{HC}$ & $\begin{array}{l}\text { Miller et al., } \\
1998\end{array}$ \\
\hline & $A b c c 7^{* *}$ & $\mathrm{HC}, \mathrm{M}, \mathrm{WB}$ & $\begin{array}{l}\text { Marshall et al., } \\
1991\end{array}$ \\
\hline & $A b c c 7^{* *}$ & $\mathrm{~F}, \mathrm{IHC}, \mathrm{WB}$ & $\begin{array}{l}\text { Lehrich et al., } \\
1998\end{array}$ \\
\hline & $A b c c 7^{* *}$ & $F, M$ & $\begin{array}{l}\text { Bewley et al., } \\
2006\end{array}$ \\
\hline & $A b c c 7^{* *}$ & $\mathrm{~F}, \mathrm{M}, \mathrm{T}$ & $\begin{array}{l}\text { Ratner et al., } \\
2006\end{array}$ \\
\hline & $A b c c 7^{* *}$ & $F, M$ & $\begin{array}{l}\text { Stahl et al., } \\
2012\end{array}$ \\
\hline & $A b c c 7^{* *}$ & $F, M$ & $\begin{array}{l}\text { De Jonge et al., } \\
2014\end{array}$ \\
\hline & $A b c c 7^{* *}$ & $F$ & $\begin{array}{l}\text { Telles et al., } \\
2016\end{array}$ \\
\hline & $A b c c 7^{* *}$ & $\mathrm{~F}$ & $\begin{array}{l}\text { Neuman et al., } \\
2018\end{array}$ \\
\hline
\end{tabular}

$B$, biochemistry; $D B$, dot blot; $F$, functional assays; IHC, immunohistochemistry or immunofluorescence; M, molecular biology; MF, molecular biology - functional; $T$, toxicology; WB, western blot; WISH, whole-mount in situ hybridization. Asterisks indicate studies on the intestine and rectum $\left(^{*}\right)$ or rectal gland $\left(^{* *}\right)$. in the intestine, the most highly expressed transporters were abce1, abcf1 and abcf2, followed by abcb1-like, abcb6, abcb7, abcb10, abcc2, abcc5, abcd2, and abcd3. In the parasite stage, the expression of abca12 transcripts was higher in the distal than in the proximal intestine. Interestingly, abcb1 was not present in this organ, but abcb1-like was highly expressed. The abcc4 and abcg2a transcripts were highly expressed only in the small parasite distal intestine.

After the first comprehensive zebrafish genome by Dean and Annilo (2005); Annilo et al. (2006) report that several duplication events and gene deaths have occurred throughout the evolution of vertebrate $\mathrm{ABC}$ genes. These changes include ancient events such as the apparent whole-genome duplication in fish and more recent events such as individual $\mathrm{ABC}$ duplications. These authors identify fifty-two zebrafish $\mathrm{ABC}$ genes (nine abca, fourteen $a b c b$, thirteen $a b c c$, five $a b c d$, one abce, three $a b c f$, nine abcg, and one abch gene). They also report more frequent duplication events in abca, abcb full-transporters, and abcg than in genes encoding abce, abcf, abcb half transporters, and abcc. Liu et al. (2013) identify a set of fifty ABC genes in the channel catfish (Ictalurus punctatus) genome, which belong to seven subfamilies: nine abca, twelve abcb, twelve abcc, five abcd, two abce, four abcf, and six abcg genes, but no abch. Jeong et al. (2015), through bioinformatics-aided in silico analyses, have characterized 50 putative $\mathrm{ABC}$ transporters in the marine medaka (Oryzias melastigma), including one putative Abch gene. From a phylogenetic analysis, these authors have determined that these $\mathrm{ABC}$ genes are members of the eight $\mathrm{ABC}$ subfamilies, including ten $a b c a$ and ten $a b c b$, thirteen $a b c c$, four abcd, one abce, three abcf, eight abcg, and one abch.

Posteriorly, Liu et al. (2016) identified 61 ABC genes representing seven subfamilies in the common carp (Cyprinus carpio) genome, including eleven abca, six abcb, nineteen abcc, eight abcd, two abce, four abcf, and eleven abcg. These authors also studied the expression of each $\mathrm{ABC}$ gene in the brain, gills, kidney, spleen, heart, and intestine by qPCR. Most of the $\mathrm{ABC}$ transcripts were ubiquitous, but their expression levels were tissue-specific. Interestingly, abca2 was detected only in the intestine. Transcripts of the remaining abca and abcb genes identified in the genome were also present in this organ, except abca12 and abcb5-1. All the abcc members were expressed in the intestine with variable intensity, except $a b c c 7$, abcc8, and abcc121 genes that were not detected. Except for the high expression of abcd4-2, the abcd genes were absent or weakly expressed in the intestine. The abce and $\mathrm{f}$ subfamilies were also present in the intestine, showing abce1-2 the highest expression levels. Finally, most abcg genes had weak expression in the intestine except for abcg5, which was abundant in all tissues.

\section{Expression and Physiological Role of Fish Intestinal ABC Proteins}

In this and the following sections, we will focus on the expression, function, toxicology, and regulation of the $\mathrm{ABC}$ proteins that have been studied so far in the fish intestine. Most of the earlier studies, particularly those based on anti-mammalian protein antibodies, use a functional terminology, e.g., Pgp, MDR, MRP. 
In cases in which the information provided or the technique applied by the original authors does not allow to identify specific $a b c / A b c$ gene/proteins, we will keep the terms Pgp or MRP of the original paper. Table 1 summarizes all the studies on fish intestine $\mathrm{ABC}$ proteins, and Figure 2 shows the localization of the most studied $A B C$ proteins in the fish enterocytes.

\section{ABCA}

In mammalian enterocytes, $\mathrm{ABCA} 1$ transports sterols and lipids through the basolateral membrane contributing to the formation of plasmatic HDL (e.g., Brunham et al., 2006). In fish, Liu et al. (2016) have reported the presence of abcal and abca2 in the common carp intestine. Furthermore, in the Atlantic salmon (Salmo salar), adding cholesterol to a plant-based diet increases the abcal and abcg5 RNA expression in the pyloric caeca, the primary site of lipid absorption (Kortner et al., 2014). Since abcal is basolateral and abcg5 is an apical transporter, this induction suggests that $S$. salar pyloric abcal and abcg5 (as $\mathrm{Abcg} 5 / 8$ heterodimer, see section "ABCG and $\mathrm{ABCH}$ ") regulate the intestinal cholesterol flux by favoring absorption or excretion, respectively, according to the cholesterol level in the diet. A possible protective role of this regulatory mechanism by exporting cytotoxic oxysterols deserves investigation.

\section{ABCB}

Phylogenetic analysis shows that fish abcb1, abcb4, and abcb5 are closely related genes, indicating a shared common ancestor during chordate evolution (Annilo et al., 2006; Fischer et al., 2013; Luckenbach et al., 2014). Formerly, Annilo et al. (2006) recognized two abcb1 genes, abcbla and abcb1b, and no abcb4 in zebrafish. They stated that ABCB4 appeared in the mammalian lineage; thus, it was absent in fish. Later, Fischer et al. (2013) showed that, in zebrafish, abcbla and abcblb corresponded to abcb5 and abcb4, respectively. The whole-genome analyses presented in the previous section of this review show that at least one of these transporters (abcb1, abcb4) is present in any genome. For example, the zebrafish and the rainbow trout have abcb4 and abcb5 but not abcb1 (Fischer et al., 2013; Luckenbach et al., 2014; Kropf et al., 2020).

Zebrafish abcb4 is highly expressed in the intestine and is the most similar fish abcb to human ABCB1 (Fischer et al., 2013; Robey et al., 2021). However, it is unclear whether the genes described in pioneering works as abcb1, abcb1-like, Mdr1, and Pgp correspond to abcb1 or abcb4. Consequently, we will use Pgp to denote genes not clearly identified as abcb1 or abcb4.

Chan et al. (1992) described for the first time the presence and the molecular structure of two Pgp genes in the winter flounder Pleuronectes americanus. From then on, studies on Abcb transporters in fish tissues have increased thanks to the availability of different methodologies, such as immunohistochemistry, immunoblot, molecular biology, model substrate transport, and ATPase activity assays.

It is important to notice that the antibodies used in the studies described herein have been raised against mammalian proteins. Therefore, their specificity toward fish representatives of the different $\mathrm{ABC}$ proteins may not be complete, or the binding to the target protein could fail. Considering this constraint, Hemmer et al. (1995) detected ABCB proteins in the guppy (Poecilia reticulata) by immunohistochemistry with four different antimammalian $\mathrm{ABCB} 1$ antibodies: $\mathrm{C} 219$, which recognizes $\mathrm{ABCB} 1$, $A B C B 4$, and $A B C B 11 ; C 494$, which recognizes ABCB1, but not $A B C B 4$, JSB-1 (which binds to a conserved epitope of $A B C B s$ ), and $\operatorname{mdr}(A b-1)$, similar to $\mathrm{C} 219$. The intestinal epithelium showed similar labeling intensity with all the antibodies, while the subjacent smooth muscle showed negative results. Another early work by Cooper (1996) reports high protein expression of Pgp in the liver and lower-level in the intestine of the killifish (Fundulus heteroclitus) by immunoblot with the antibody C219.

Similarly, Kleinow et al. (2000) identified a Pgp protein in the apical border of the intestinal epithelium of the channel catfish intestine by immunohistochemistry with C219. The previous oral exposure of these fish to the human Pgp agonist, vincristine, or $\beta$-naphthoflavone (an agonist of the aryl hydrocarbon receptor, AhR) increased the Pgp immunostaining. Tutundjian et al. (2002) studied the expression pattern of a DNA sequence that was 73\% identical to several mammalian $\mathrm{ABCB}$ sequences in the turbot (Scophthalmus maximus). They detected the highest mRNA expression in the brain, intestine, and kidney. In contrast, their Western blot studies with C219 showed higher protein expression in the kidney and brain than in the intestine, heart, and gills.

Costa et al. (2013) have reported that C494 (specific for ABCB1) labels enterocytes and vascular endothelium of the Nile tilapia (Oreochromis niloticus). They have also found that C219 labels the apical membrane of the enterocytes. Umans and Taylor (2012) studied Pgp functions in the zebrafish larvae blood-brain barrier and intestine. Concerning the intestinal mucosa, these authors showed positive immunostaining with C219. They confirmed the detected protein's functionality by exposing the larvae to the mammalian ABCB1 fluorescent substrate doxorubicin in water and measuring its accumulation in the intestinal lumen. Table 2 details the antibodies used in the papers cited in this review.

Fischer et al. (2013) report that unlike the mammalian ABCB4 (which has a different substrate affinity), zebrafish Abcb4 is functionally similar to the mammalian ABCB1. Besides, these authors have examined whether Abcb4 or Abcb5 participate in xenobiotic efflux through rhodamine $B$ and calcein accumulation assays performed in morpholino-knockdown embryos. They have concluded that the changes in rhodamine B or calcein accumulation occur specifically in Abcb4 knockdown; thus, Abcb4, but not Abcb5, acts as an efflux pump for those substrates. Using recombinant Abcb4 zebrafish protein, these authors have confirmed the detoxification function of Abcb4 by studying the effects of fluorescent dyes and well-known human ABCB1 substrates on ATPase activity. Bieczynski et al. (2021) established an automated microscopy-based rhodamine B dye accumulation assay for studying the interaction between several well-known human $\mathrm{ABC}$ substrates/inhibitors and aquatic pollutants with Abcb4 in zebrafish embryos; and also analyzed the effects of these substances on the ATPase activity of recombinant zebrafish Abcb4. These two assays confirmed that Abcb4 functions as a broad-spectrum multixenobiotic efflux transporter in zebrafish, as previously described by Fischer et al. (2013). However, the results from both tests were not always concordant. In adult 

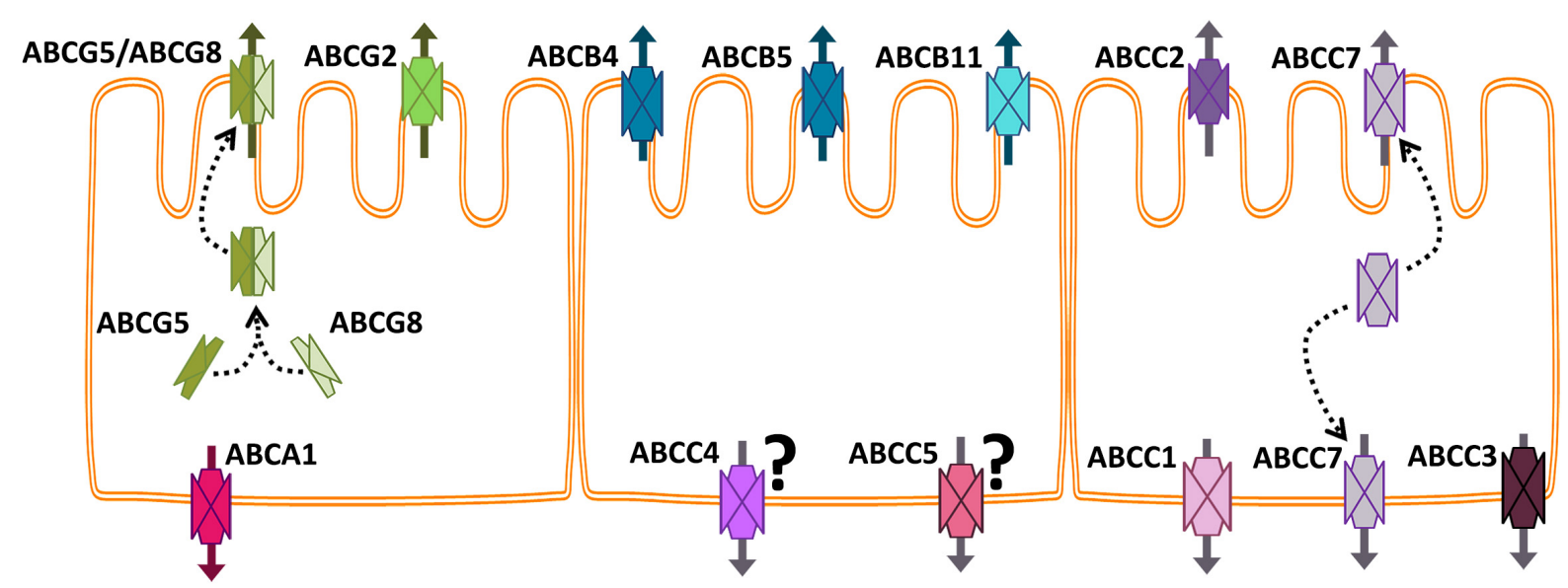

FIGURE 2 | Schematic representation of the intestinal epithelium showing the most studied fish ABC proteins localized. Arrows indicate the direction of the substrates' transport. The question mark next to ABCC4 and ABCC5 indicates that the basolateral location of these proteins in the intestine has not been confirmed yet for fish.

zebrafish, Lu et al. (2015) found the highest abcb4 mRNA expression in the intestine, followed by the liver, and then muscle $>$ gill $>$ eye $>$ ovary $>$ testis $>$ heart $>$ brain $>$ kidney, suggesting a vital role of Abcb4 transporters in the barrier function of the intestinal mucosa.

Gordon et al. (2019) have shown that zebrafish Abcb5 has Pgp functions but different substrate affinity from Abcb4. They detected high RNA expression of abcb5 in proton pumprich ion-transporting cells (HR ionocytes) of the epidermis of zebrafish embryos through single-cell transcriptomics. HR cells accumulate several fluorescent $\mathrm{ABC}$ substrates but not rhodamine $\mathrm{B}$, and the addition of $\mathrm{ABCB} 1$ and $\mathrm{ABCC}$ inhibitors significantly increase this accumulation. These results suggest a protective role of the epidermis ionocytes in part through Abcb5-mediated efflux of toxic molecules in early stages with not completely developed detoxification organs.

Robey et al. (2021) provide further information on the function and expression patterns of abcb4 and abcb5 in zebrafish. Immunofluorescence and in situ hybridization show that abcb4/Abcb4 is more expressed than abcb5/Abcb5 in the blood-brain barrier, intestine, and liver. Additionally, using transfected cells, they have compared both Abcbs' substrate specificity through a cytotoxicity assay with known human ABCB1 substrates. They report that both transporters confer similar resistance levels as human ABCB1 to vinblastine and paclitaxel, although Abcb4 confers higher resistance to bisantrene, mitoxantrone, and doxorubicin than Abcb5. Abcb4 and Abcb5 share a similar affinity for the fluorescent ABCB1 substrates calcein-AM, rhodamine 123, BODIPYprazosin, Flutax, BODIPY-vinblastine, and TMRE. However, only Abcb4 transports the substrates LDS 751 and BODIPYEDA. The set of ABCB1 specific inhibitors tested by these authors inhibits the efflux of most of these substrates by both, Abcb4 and Abcb5 to a similar extent. Finally, a high throughput screening with 90 cytotoxic human ABCB1 substrates led the authors to conclude that zebrafish Abcb4 is functionally homolog to human ABCB1.
In the same report, ATPase activity and molecular structure studies complete the analysis on the homologies of zebrafish Abcb4 and Abcb5. Both proteins partially differ from human $\mathrm{ABCB} 1$ in the drug-binding pocket; however, Abcb5 has more significant differences in amino acids relative to $\mathrm{ABCB} 1$ than Abcb4. This result could explain the difference in substrate specificity between these proteins.

Most studies on Abcb11 refer to the liver, where this protein localizes to the hepatocytes apical membrane and transports bile salts in the rate-limiting step of the hepatocyte bile secretion (Boyer and Soroka, 2021). The zebrafish genome predicts the presence of two co-orthologs of the human ABCB11, abcb11a, and abcb11b (Ellis et al., 2018). By whole-mount in situ hybridization, these authors have identified abcb1la as the predominant isoform in the intestine, while abcb11b RNA is specifically expressed in the liver.

\section{$A B C C$}

Lončar et al. (2010) analyzed the mRNA expression of a set of $\mathrm{ABC}$ transporters in rainbow trout tissues. They detected the presence of abccl to 5 in the anterior and posterior intestine, showing a much larger number of transcript copies of abcc3 than the others ABCC. However, the relative abundance of the different abcc transcripts is subject to modulation by endogenous or exogenous factors (see citation to Cárcamo et al., 2011 in section "Pesticides and Pharmaceuticals").

Miller et al. (1998) showed that, besides its primary role in osmotic-ionic regulation, the rectal gland of the elasmobranches could actively excrete xenobiotics through an analog of ABCC2. These authors studied the transport of the fluorescent substrates sulforhodamine 101 and fluorescein methotrexate combined with known ABC substrates/inhibitors in isolated dogfish shark (Squalus acanthias) rectal gland tubule fragments. This transport was sensitive to cyclosporine A, chloro-dinitrobenzene (CDNB), and leukotriene C4 but not the Pgp inhibitor verapamil. Besides, they have confirmed the presence of $\mathrm{Abcc} 2$ in the luminal membrane of the rectal gland 
TABLE 2 | Antibodies utilized to detect fish intestine ABC proteins.

\begin{tabular}{|c|c|c|c|c|}
\hline Antibody & $\begin{array}{l}\text { Protein } \\
\text { detected }\end{array}$ & Technique & Species & References \\
\hline \multirow[t]{9}{*}{$\mathrm{C} 219$ (m) } & $\begin{array}{l}\text { Human MDR1 } \\
\text { (ABCB1), } \\
\text { MDR2/3 } \\
\text { (ABCB4), and } \\
\text { BSEP } \\
\text { (ABCB11) }\end{array}$ & $\mathrm{HC}$ & Poecilia reticulata & $\begin{array}{l}\text { Hemmer et al., } \\
1995\end{array}$ \\
\hline & & IHC, WB & $\begin{array}{l}\text { Fundulus } \\
\text { heteroclitus }\end{array}$ & Cooper, 1996 \\
\hline & & $\mathrm{IHC}$ & Ictalurus punctatus & $\begin{array}{l}\text { Kleinow et al., } \\
2000\end{array}$ \\
\hline & & WB & Ictalurus punctatus & Doi et al., 2001 \\
\hline & & WB & $\begin{array}{l}\text { Scophthalmus } \\
\text { maximus }\end{array}$ & $\begin{array}{l}\text { Tutundjian } \\
\text { et al., } 2002\end{array}$ \\
\hline & & $\mathrm{HC}, \mathrm{WB}$ & $\begin{array}{l}\text { Fundulus } \\
\text { heteroclitus }\end{array}$ & $\begin{array}{l}\text { Bard et al., } \\
2002\end{array}$ \\
\hline & & IF & Danio rerio & $\begin{array}{l}\text { Umans and } \\
\text { Taylor, } 2012\end{array}$ \\
\hline & & IF, WB & $\begin{array}{l}\text { Oreochromis } \\
\text { niloticus }\end{array}$ & $\begin{array}{l}\text { Costa et al., } \\
2013\end{array}$ \\
\hline & & IF & Danio rerio & $\begin{array}{l}\text { Robey et al., } \\
2021\end{array}$ \\
\hline$m d r(A b-1)(p)$ & & $\mathrm{HC}$ & Poecilia reticulata & $\begin{array}{l}\text { Hemmer et al., } \\
1995\end{array}$ \\
\hline \multirow[t]{2}{*}{ C494 (m) } & $\begin{array}{l}\text { Human MDR1 } \\
\text { (ABCB1) }\end{array}$ & $\mathrm{IHC}$ & Poecilia reticulata & $\begin{array}{l}\text { Hemmer et al., } \\
1995\end{array}$ \\
\hline & & IF, WB & $\begin{array}{l}\text { Oreochromis } \\
\text { niloticus }\end{array}$ & $\begin{array}{l}\text { Costa et al., } \\
2013\end{array}$ \\
\hline JSB-1 (m) & Human MDR & $\mathrm{IHC}$ & Poecilia reticulata & $\begin{array}{l}\text { Hemmer et al., } \\
1995\end{array}$ \\
\hline EAG15 (p) & Rat ABCC2 & $\mathrm{HC}$ & Squalus acanthias & $\begin{array}{l}\text { Miller et al., } \\
1998\end{array}$ \\
\hline $\begin{array}{l}\text { Anti-skate } \\
\text { Abcc2 (p) }\end{array}$ & Skate Abcc2 & IF & Raja erinacea & Cai et al., 2003 \\
\hline \multirow[t]{8}{*}{ Anti-CFTR (m) } & $\begin{array}{l}\text { Human CFTR } \\
\text { (ABCC7) }\end{array}$ & $\mathrm{HC}, \mathrm{WB}$ & Squalus acanthias & $\begin{array}{l}\text { Marshall et al., } \\
1991\end{array}$ \\
\hline & & IF, WB & $\begin{array}{l}\text { Fundulus } \\
\text { heteroclitus }\end{array}$ & $\begin{array}{l}\text { Marshall et al., } \\
2002\end{array}$ \\
\hline & & IF, WB & $\begin{array}{l}\text { Dicentrarchus } \\
\text { labrax }\end{array}$ & $\begin{array}{l}\text { Bodinier et al., } \\
\text { 2009a }\end{array}$ \\
\hline & & $\mathrm{DB}, \mathrm{IF}$ & $\begin{array}{l}\text { Dicentrarchus } \\
\text { labrax }\end{array}$ & $\begin{array}{l}\text { Bodinier et al., } \\
\text { 2009b }\end{array}$ \\
\hline & & IF & Sparus aurata & $\begin{array}{l}\text { Gregório et al., } \\
2013\end{array}$ \\
\hline & & IF & $\begin{array}{l}\text { Oreochromis } \\
\text { mossambicus }\end{array}$ & Li et al., 2014 \\
\hline & & IF & Opsanus beta & $\begin{array}{l}\text { Ruhr et al., } \\
2014\end{array}$ \\
\hline & & IF & Opsanus beta & $\begin{array}{l}\text { Ruhr et al., } \\
2018\end{array}$ \\
\hline $\begin{array}{l}\text { Anti-lamprey } \\
\text { CFTR (p) }\end{array}$ & $\begin{array}{l}\text { Lamprey Cftr } \\
\text { (Abcc7) }\end{array}$ & $\mathrm{HC}, \mathrm{WB}$ & $\begin{array}{l}\text { Petromyzon } \\
\text { marinus }\end{array}$ & Cui et al., 2019 \\
\hline MAB25031 (m) & $\begin{array}{l}\text { Human CFTR } \\
\text { (ABCC7) }\end{array}$ & $\mathrm{IHC}$ & Anguilla japonica & $\begin{array}{l}\text { Wong et al., } \\
2016\end{array}$ \\
\hline R3195 (p) & $\begin{array}{l}\text { Rodent CFTR } \\
\text { (ABCC7) }\end{array}$ & IF, WB & Squalus acanthias & $\begin{array}{l}\text { Lehrich et al., } \\
1998\end{array}$ \\
\hline
\end{tabular}

$\overline{D B}$, dot blot; IF, immunofluorescence; IHC, immunohistochemistry; m, monoclonal; p, polyclonal; WB, western blot. epithelial cells by immunohistochemistry with a polyclonal antimammalian ABCC2 antibody (Table 2). Posteriorly, Miller et al. (2002) described a hormonal regulatory pathway for the rectal gland Abcc2-mediated transport similar to that described by Masereeuw et al. (2000) for the killifish renal tubules. Endothelin1 (ET1) inhibited sulforhodamine 101 transport through an $\mathrm{ET}_{B}$ receptor that induces protein kinase (PKC).

In the same paper, Miller et al. (2002) reported that the activation of the cAMP pathway by forskolin inhibits the luminal Abcc2-mediated transport by a PKA-independent mechanism. Applying a cAMP analog that does not activate PKA produced a similar effect, suggesting that cAMP could interact directly with the transporter, possibly as a competitive substrate. In this case, the transport of cyclic nucleotides by Abcc2 or other apical Abcc could be part of the modulation of apical ion transport proteins, thus regulating the rectal gland's primary function.

Cai et al. (2003) studied the molecular structure and properties of the little skate (Raja erinacea) Abcc2 and found phylogenetic and structural similarities with the mammalian ABCC2. Their immunofluorescence studies with a specific anti-skate Abcc2 antibody localize this protein at the apical membrane of hepatocytes, kidney tubules cells, and small intestine enterocytes.

As for teleosts, a whole-mount in situ hybridization and qRTPCR study in developing and adult zebrafish (Long et al., 2011c) shows that after $72 \mathrm{hpf}$, abcc2 has the highest expression in the intestine, followed by the kidney and the liver. In agreement, Fischer et al. (2013) report high RNA expression of abcc2 in rainbow trout intestinal cells (RTgutGC). In contrast, Lončar et al. (2010) detected abcc2 transcripts in the rainbow trout intestine but at lower levels than other $\mathrm{ABC}$ transporters such as abcg2 and abcb4.

Bieczynski et al. (2014) report the apical transport of the ABCC substrate DNP-SG in polarized preparations of rainbow trout middle and distal intestine. This transport is sensitive to the specific ABCC inhibitor MK571 suggesting the involvement of Abcc2. Painefilú et al. (2019) show that the previous exposure of rainbow trout to arsenic (as AsIII) for $48 \mathrm{~h}$ increases the rate of apical DNP-SG extrusion in intestinal preparations and that this effect coincides with the induction of abcc2 mRNA expression (more details in section "Toxicological Studies").

Long et al. (2011a) suggest that zebrafish Abcc5 may be involved in tissue defense against xenobiotics and embryonic development and maintenance of normal physiological functions through the transport of cyclic nucleotides such as cGMP. Transcripts of this gene are ubiquitous in embryos, and since $96 \mathrm{hpf}$, abcc5 expression is evident in the intestine, among other organs. Besides, blockade of Abcc5 activity in embryos overexpressing an inactive $\mathrm{Abcc5}$ form retards development and increases cGMP levels. In contrast, embryos that overexpress the typical Abcc5 show normal development and maintain a cGMP concentration similar to that of control embryos.

Sun et al. (2021) used abcc6a mutant zebrafish as a model to increase knowledge of the mechanisms underlying the human disease Pseudoxanthoma elasticum multisystem disorder (PXE). Besides the effects on other organs, these authors report the presence of abcc6 transcripts in the intestine muscularis external and lamina propria and weak expression in some enterocytes. 
They have found that abcc6aD1/D1 mutants have PXE-like symptoms, such as fibrosis and thickening of the muscularis external and lamina propria compared to wild-type fish, but not detectable calcification in the intestine.

Abcc7 (CFTR) is a chloride channel extensively studied in seawater teleosts, lampreys, and elasmobranchs concerning ion transport and water balance (Marshall et al., 2002, 2009; Grosell, 2006, 2011; Takei and Yuge, 2007; Bodinier et al., 2009a,b; Evans, 2010; Gregório et al., 2013; Ruhr et al., 2018; Cui et al., 2019). The intestine of seawater fish can switch from net ion absorption to net ion secretion by regulating the expression, activity, and localization of different channels and transporters, such as NKCC2, HCO3-/ Cl-, and Abcc7 in the enterocytes. These events are under endocrine control and respond to intracellular stimuli, which activate cyclic AMP and GMP pathways (Takei and Yuge, 2007; De Jonge et al., 2014; Ruhr et al., 2014, 2018; Ando and Takei, 2015; Forrest, 2016; Kinne et al., 2020). Pioneering works studied Abcc7 in the rectal gland of elasmobranchs. This model allowed the authors to know that the Abcc7 phosphorylation by the CAMP-PKA pathway stimulates its traffic to the apical membrane and the opening of the Abcc7 channel (Marshall et al., 2002; Evans, 2010; Forrest, 2016 for reviews). Nowadays, there are numerous studies on this transporter's cellular location, function, and regulation by immunohistochemistry, molecular and electrophysiological techniques in teleosts, elasmobranchs and lampreys' gills, opercular epithelium, skin, pancreas, intestine, and rectum (Marshall et al., 2002, 2005; De Jonge et al., 2014; Forrest, 2016; Ruhr et al., 2018; Cui et al., 2019). Table 1 summarizes the studies on abcc7/Abcc7 performed exclusively in the fish intestine, rectum, and rectal gland.

Wong et al. (2016) studied the structure and function of the abcc7 isoforms $\mathrm{a}$ and $\mathrm{b}$ in the Japanese eel by qPCR and immunohistochemistry. They reported that abcc7a (and its protein product Abcc7a) is the dominant isoform in the intestine and kidney. Its expression is higher in freshwater than in seawater. On the contrary, $a b c c 7 b / A b c c 7 b$ is present predominantly in the gills, and its expression augments in seawater conditions. Cui et al. (2019) examined an ancient abcc7 ortholog found in the sea lamprey, the earliest known abcc7. These authors studied the abcc7/Abcc7 distribution in the sea lamprey intestine by qPCR and immunoblot. In adults and larvae, they found high mRNA and protein expression in the distal portion of the gastrointestinal system.

\section{$A B C G$ and $A B C H$}

In contrast with mammals, which have only one ABCG2, fish possess multiple copies of this gene. For example, there are two paralog genes (abcg2a and abcg $2 \mathrm{~d}$ ) in the rainbow trout genome, and four predicted abcg2 (a-d) in the zebrafish genome (Annilo et al., 2006). These abcg 2 paralogs are differentially expressed among zebrafish tissues. While abcg $2 \mathrm{a}$ and $\mathrm{abcg} 2 \mathrm{~b}$ have a strong expression in the intestine, abcg2c is highly expressed in the gills, intestine, spleen, and kidney but not in the liver. In contrast, these authors could not find abcg2d expression in any tissue (Kobayashi et al., 2008).
Zaja et al. (2016) studied the properties of the rainbow trout Abcg $2 \mathrm{a}$ by expressing the transporter in Sf9 insect cells and analyzing the effects of several toxic compounds on ATPase activity. They have obtained similar results to those obtained for mammalian ABCG2. The model ABCG2 activator, sulfasalazine, caused maximum ATPase activation at $100 \mu \mathrm{M}$. Curcumin, benzo (a) pyrene (BaP), and testosterone produced the highest activation (maximum effects with 1,10 , and $100 \mu \mathrm{M}$, respectively).

Matsumoto et al. (2020) have cloned and studied the distribution pattern of abcg2 in the marine pufferfish. They have detected two abcg2 genes with the highest RNA expression in the intestine, liver, and kidneys. Their phylogenetic analysis assigns the pufferfish abcg2 to the abcg2b gene paralog group. In addition, these authors report a hypoxia response element and an estrogen response element located upstream of the abcg2 sequence, suggesting that the transcriptional regulation of the pufferfish abcg2 responds to sex hormones and is induced by the hypoxia-inducible factor, as it occurs for the human ABCG2.

Abcg5 and Abcg8 proteins are present in the Atlantic salmon pyloric caeca and the zebrafish intestine (Kortner et al., 2014; Zhang L. et al., 2020). Besides a possible physiological role in biliary and intestinal transport of neutral sterols, reported for mammalian ABCG5/8, Zhang L. et al. (2020) suggest that zebrafish Abcg5/8 could transport organochlorine pesticides (see section "Toxicological Studies”).

$\mathrm{Abch} 1$ is a relatively recently discovered $\mathrm{ABC}$ transporter. Popovic et al. (2010) have detected abch1 through qPCR analysis in different zebrafish tissues, including the intestine. Jeong et al. (2015) report the presence of Abch1 in the marine medaka. These authors suggest that considering the moderate similarity in topology and tissue distribution pattern between Abch1 and ABCG transporters, Abch1 can be involved in sterol transport similar to Abcg1 or MXR defense, like Abcg2. However, there are no functional studies about fish intestine $\mathrm{ABCG}$ or $\mathrm{ABCH}$ transporters as far as we know.

\section{ABC DISTRIBUTION ALONG THE FISH INTESTINE}

Lončar et al. (2010) studied the expression by qPCR of abcb4, abcb11, abcc1 to 5, and abcg2 in different rainbow trout tissues. In the proximal intestine, the expression of abcc3 was 2-3fold higher than that of abcg2, followed by abcb11, abcb4, and abcc5 $>$ abcc $2>$ abcc1 and abcc4. In contrast, the distal intestine showed the highest level of abcg2 and abcb4, followed by abcc 3 and abcc2. The abcb4 expression was more than 7 fold higher in the distal than in the proximal part. Accordingly, immunohistochemical studies reported higher reaction with the anti-Pgp antibody C219 in the distal than in the proximal intestine of the channel catfish (Kleinow et al., 2000) and the killifish (Bard et al., 2002). In addition, Costa et al. (2013) reported increasing label intensity with another anti-Pgp antibody, C494, from the crypts to the tips of the intestinal folds in the Nile tilapia proximal intestine. These distribution patterns are similar to the reported for human and rodent intestinal 
ABCB1 mRNA and protein expression (Mottino et al., 2000; Chan et al., 2004; Müller et al., 2016).

Fischer et al. (2011) studied the expression of abcb4, abcb5, abcb11, abcc1 to 5 , and abcg2 in seven rainbow trout permanent cell lines using qRT-PCR and functional assays (fluorescence substrate accumulation, combined with different $\mathrm{ABC}$ inhibitors). They found that transcripts of all the studied transporters were present in the seven rainbow trout cell lines, having abcc 2 the highest expression. In the intestine cell line RTgutGC, the order of expression was: $a b c c 2>a b c c 3=a b c c 1>a b c c 5>a b c c 4=a b c g 2>a b c b 4>a b c b$ $11>$ abcb5. The ABC expression between the intestine and the RTgutGC model shows marked differences; especially, the cell line has higher abcc2 expression than the intestine. Besides, the most expressed transporters in the intestine, abcg2, and abcb4, show weak expression in the RTgutGC cell line (Lončar et al., 2010; Fischer et al., 2011). The differential transporter expression between tissues and cell cultures could lead to erroneous conclusions from functional or toxicological experiments. For example, Boaru et al. (2006) observed no effects of the cyanotoxin microcystin-LR (MCLR) on RTL-W1 and RTgutGCl cell lines (from rainbow trout's liver and intestine, respectively), neither on $\mathrm{HepG} 2$ and $\mathrm{CaCo} 2$ (human), which was an unexpected result. Then, these authors analyzed the expression of OATP (organic anion-transporting polypeptides), the proteins by which MCLR would enter the cells in the RTL-W1 and RTgutGCl cell lines and rainbow trout primary hepatocytes. They detected no oatp mRNA expression in the rainbow trout cell lines. In contrast, freshly prepared primary hepatocytes expressed oatp mRNA and were sensitive to MCLR, but this expression decreased drastically $24 \mathrm{~h}$ after preparation.

Functional and toxicological studies also suggest a specific $\mathrm{ABC}$ distribution pattern along the intestine. For example, in ex vivo intestinal preparations from the Patagonian silverside, the apical and basolateral DNP-SG efflux was significantly inhibited by microcystin-LR in the anterior and middle intestine; however, neither apical nor basolateral DNP-SG efflux transport was affected in the posterior intestine (Bieczynski et al., 2016). Table 3 offers a list of representative physiological and toxicological fish $\mathrm{ABC}$ proteins' substrates.

\section{TOXICOLOGICAL STUDIES}

This section presents the current literature on the effects of environmental pollutants on the expression and function of fish $\mathrm{ABC}$ proteins, emphasizing intestinal ones and the available evidence on the role of these proteins in pollutants detoxification. It is important to consider that the primary function of $\mathrm{ABC}$ transporters is to pump metabolites and potentially harmful molecules out of the cells. Concerning the individual's defense, the cellular location of a transporter in a polarized epithelium like the intestinal mucosa, the liver, gills, and kidney tubules determines its function. In the intestinal mucosa, apical transporters, such as Abcb1/4, Abcb5, Abcc2, and Abcg2, play a protective role as a barrier against the absorption of xenobiotics. In turn, basolateral proteins, such as Abccl, and $A b c c 3$, export toxic compounds to the blood for further detoxification in the liver or the kidney.

\section{Cyanotoxins}

Cyanobacteria are one of the main phytoplankton components of most bodies of water and are thus significant components in the diet of phytoplanktivorous species (Ferrão-Filho et al., 2002; Pires et al., 2004; Xie et al., 2004, 2005). Under favorable conditions, cyanobacteria may reach massive cell densities, called cyanobacterial blooms (see Chorus and Bartram, 1999; Huisman et al., 2018 for reviews). Many species of this group can produce toxic secondary metabolites (cyanotoxins), which affect human and ecosystems health (Wiegand and Pflugmacher, 2005; Huang and Zimba, 2019 for reviews).

Microcystins (MC) are mainly intracellular cyclic peptide toxins produced by cyanobacteria of several genera. Thus, fish's absorption of these toxins mostly depends on the ingestion and digestion of cyanobacterial cells and occurs in the gastrointestinal tract (Tencalla et al., 1994; Bury et al., 1998; Bieczynski et al., 2013). According to functional and molecular studies on fish, humans, and rodents, this toxin enters the cells through OATP bile acid transporters (Bury et al., 1998; Fischer et al., 2005; Boaru et al., 2006; Feurstein et al., 2010). This toxin exerts its specific effect by inhibiting protein phosphatases 1 (PP1) and 2A (PP2A) by non-covalent and covalent interactions (MacKintosh et al., 1990), disrupting the regulation of many cellular functions and less specific effects like damage to lysosomes and oxidative stress (Carmichael, 1994; Boaru et al., 2006; Amado and Monserrat, 2010 for a review). Inside the cells, a phase II biotransformation reaction catalyzed by enzymes of the family glutathione $-S$ transferase (GST) conjugates MCLR with glutathione (GSH) (Pflugmacher et al., 1998). As analyzed below, the mechanisms for eliminating MCLR are still not entirely established but likely involve $\mathrm{ABC}$ protein-mediated transport.

Bieczynski et al. $(2014,2016)$ have studied the detoxification and efflux mechanisms of MCLR (the most studied and one of the most harmful MC) and other xenobiotics in the anterior, middle, and posterior intestine of the Patagonian silverside and the middle and distal intestine of the rainbow trout using in vivo, ex vivo, and in vitro techniques. Experiments with intestinal non-polarized (strips) and polarized (everted or non-everted sacs) ex vivo preparations and combining the studied xenobiotics with specific ABCC substrates, such as the GSH conjugate of 1-chloro-2,4-dinitrobenzene (CDNB), 2,4dinitrophenyl glutathione (DNP-SG), and calcein; show that MCLR inhibits the efflux activity of apical and basolateral Abcc proteins in both species (Bieczynski et al., 2014, 2016). In addition, the coexposure to MCLR and the specific ABCC inhibitor MK571 increases the toxic effects of MCLR, which indicates that blocking the $\mathrm{Abcc}$ transport increases the intracellular MCLR concentration. These results suggest the involvement of apical Abcc2 in MCLR detoxification, while basolaterally located Abcc proteins protect the enterocytes from the remaining toxin.

The in vivo exposure of the rainbow trout to MCLR through the diet for 12, 24, and $48 \mathrm{~h}$ induces the intestine GST activity. In intestinal strips, the DNP-SG transport rate decreases at $12 \mathrm{~h}$, 
TABLE 3 | Representative chemical compounds, which interact with fish ABC proteins presented in alphabetical order.

\begin{tabular}{|c|c|c|}
\hline ABC protein & $\begin{array}{l}{ }^{1} \text { Physiologic, }{ }^{2} \text { Drugs/Experimental substrates and }{ }^{3} \text { toxicological } \\
\text { substrates }\end{array}$ & References \\
\hline Abca & ${ }^{1}$ Sterols*, phospholipids & Fang et al., 2013, 2014; Kortner et al., 2014* \\
\hline $\begin{array}{l}\text { Abcb4, Abcb5 } \\
\text { (Pgp) }\end{array}$ & $\begin{array}{l}{ }^{1} \text { Lipophilic compounds, e.g., steroid hormones }{ }^{2} \text { Ca-AM, cyclosporin A, } \\
\text { daunomycin, doxorubicin*, etoposide, ivermectin, R123, verapamil, } \\
\text { vinblastine, and several therapeutic human drugs }{ }^{3} \text { Azinphos-methyl, Cd, } \\
\text { Hg, MCLR, phenanthrene, Zn }\end{array}$ & $\begin{array}{l}\text { Miller, 1995; Doi et al., 2001; Zaja et al., 2007; Caminada et al., 2008; } \\
\text { Zaja et al., 2011; Umans and Taylor, 2012*; Fischer et al., 2013; Lu } \\
\text { et al., 2015; Lerebours et al., 2016; Ellis et al., 2018; Gordon et al., } \\
\text { 2019; Bieczynski et al., 2021; Robey et al., 2021; }\end{array}$ \\
\hline Abcb11 (Bsep) & ${ }^{1}$ Bile salts and bile alcohols ${ }^{2}$ DHFDA & Ballatori et al., 2000; Zaja et al., 2008; Ellis et al., 2018 \\
\hline $\begin{array}{l}\text { Abcc2 and BL } \\
\text { ABCCs (MRPs) }\end{array}$ & $\begin{array}{l}{ }^{1} \text { Leukotrienes }{ }^{\star} \text {, bilirubin, estrogen conjugates, organic anions, other } \\
\text { conjugated metabolites, cyclic nucleotides }(\mathrm{Abcc} 4, \mathrm{Abcc5}){ }^{2} \mathrm{Ca}-\mathrm{AM}^{\star} \text {, } \\
\mathrm{CDNB}^{\star} \text {, fluorescein methotrexate}{ }^{\star}, \mathrm{MK} 571^{\star}, \mathrm{R} 123 \text {, sulforhodamine } 101^{*} \text {, } \\
{ }^{3} \mathrm{As}^{\star}, \mathrm{Cd}, \mathrm{DDT}, \mathrm{Pb} \text {, lindane, MCLR }{ }^{\star}, \mathrm{Hg}\end{array}$ & $\begin{array}{l}\text { Miller et al., 1998*, 2002, 2007; Masereeuw et al., 2000; Reichel et al., } \\
\text { 2008; Zaja et al., 2008; Long et al., 2011a,c; Bieczynski et al., 2014, } \\
\text { 2016*; Lu et al., 2014, 2021; Painefilú et al., 2019, 2020* }\end{array}$ \\
\hline Abcc7 (Cftr) & ${ }^{1}$ Chloride $^{*}$ Mercury $^{*}$ & $\begin{array}{l}\text { Ratner et al., 2006*; Weber et al., 2006*; Reviewed by Evans, 2010*; } \\
\text { Forrest, 2016* }\end{array}$ \\
\hline Abcg2 (Bcrp) & $\begin{array}{l}{ }^{1} \text { Bile salts, testosterone }{ }^{2} \text { Doxorubicin, fenofibrate, furosemide, Ko143, } \\
\text { pheophorbide, prazosin, propranolol, sildenafil }{ }^{3} \mathrm{BaP}, \mathrm{DDE} \text {, chlorpyrifos, } \\
\text { curcumin (natural product), endosulfan, fenoxycarb, malathion }\end{array}$ & Zaja et al., 2011, 2016 \\
\hline Abcg5, Abcg8 & ${ }^{1}$ Neutral sterols ${ }^{*}$ Lindane & Kortner et al., 2014*; Zhu et al., 2018; Zhang L. et al., 2020 \\
\hline
\end{tabular}

BaP, benzo(a)pyrene; BL, basolateral; Ca-AM, calcein-AM; CDNB, 1-chloro-2,4-dinitrobenzene; DDE, dichlorodiphenyldichloroethylene; DDT, dichlorodiphenyltrichloroethane; DHFDA, dihydrofluorescein diacetate; MCLR, microcystin-LR; R123, rhodamine 123.

The asterisk $\left(^{*}\right)$ indicates studies performed on fish intestines or rectal glands.

is recovered at $24 \mathrm{~h}$, and rises at $48 \mathrm{~h}$, suggesting increased Abcc activity. However, this GST and Abcc activity modulation does not correlate with changes in abcc 2 , gst- $\pi$, or gst- $\omega$ mRNA expression. The study of polarized preparations shows that the apical DNP-SG transport rate recovers to control levels at $48 \mathrm{~h}$. In contrast, the basolateral transport reaches a significantly higher rate than the control at the same time, suggesting the induction of a basolateral Abcc, such as Abcc1, Abcc3, or Abcc4 (Painefilú, 2021). Kaur et al. (2019) have studied the involvement of human $\mathrm{ABC}$ proteins in the excretion of MCs. Using insect cell membrane vesicles overexpressing human $\mathrm{ABC}$ transporters together with specific substrates and inhibitors, they have found that only ABCC2 transports MCs in a congener-specific fashion (MCLF > MCLR > MCRR). In contrast, MCs do not interact with $\mathrm{ABCB} 1, \mathrm{ABCB} 11, \mathrm{ABCC} 1,3,5$, or ABCG2. These results coincide with those described above on the involvement of ABCC2/Abcc2 in MC efflux. However, the substrate affinity of other ABCC-Abcc proteins seems to differ between human and fish transporters and deserves further experiments with more comparable methodologies.

Abcb4 has been related to MCLR transport as well. Lu et al. (2015) showed that MCLR is toxic for zebrafish embryos and causes a concentration-dependent increase in abcb4 transcripts. A whole-mount in situ hybridization assay detected this induction in the embryos' intestinal region. Moreover, mutant embryos (with a non-functional abcb4) suffered higher mortality and accumulated more MCLR than the controls, indicating abcb4 involvement in embryo protection against MCLR.

Paralytic shellfish toxins (PST) are neurotoxic alkaloids produced by marine dinoflagellates and freshwater cyanobacteria that inhibit voltage-gated sodium (and other cations) channels, affecting the membrane potential in nerve and muscle cells (Lagos, 2003; Wiese et al., 2010 for reviews). In mammalian models, intestinal PST absorption proceeds through a paracellular way (Andrinolo et al., 2002a,b; Torres et al., 2007), and they are excreted by glomerular filtration or in the bile (Gessner et al., 1997; García et al., 2004, 2010). Ramos et al. (2018) have reported ABCB1 as a PST transporter.

In contrast, PST transport in the fish intestine or other organs has received little attention. Our laboratory studies show that, at least in part, PST absorption follows a transcellular pathway since PST enter the rainbow trout enterocytes through the luminal membrane and damage the lysosomal membrane. These toxins inhibit basolateral but not apical Abcc-mediated transport. However, the coexposure with the Abcc inhibitor MK571 does not increase the cytotoxic effects of PST, suggesting that these toxins are not Abcc substrates but non-competitive inhibitors (Painefilú et al., 2020).

\section{Inorganic Pollutants}

Glutathione -S transferase -mediated conjugation with GSH is a critical detoxification step for metals and metalloids. These conjugates are then extruded from cells by ABCC transporters (Singhal et al., 1987; Kala et al., 2000; Painefilú et al., 2019).

(Long et al., 2011a,b,c) have analyzed the role of zebrafish Abcc5, Abcc2, and Abcc4 in the detoxification of metals and metalloids, $\mathrm{Cd}, \mathrm{Hg}, \mathrm{Pb}$, and arsenic (AsIII, AsV). Their qPCR analysis indicates that the exposure of embryos to different concentrations of $\mathrm{Cd}, \mathrm{Hg}, \mathrm{As}$, or $\mathrm{Pb}$ for 24-48 $\mathrm{h}$ induces abcc5 mRNA expression. Exposure of adult zebrafish for $24 \mathrm{~h}$ induces abcc 5 expression in 10 different tissues. In particular, $\mathrm{Pb}$ and $\mathrm{AsV}$ induce intestine abcc5 transcription, but $\mathrm{Cd}$ has the opposite effect. In addition, embryos overexpressing abcc5 have a lower death rate than control embryos upon metal exposure (Long et al., 2011a).

Long et al. (2011c) have studied the RNA expression changes of abcc2 in developing and adult zebrafish exposed to $\mathrm{Cd}, \mathrm{Hg}$, AsIII, or $\mathrm{Pb}$. Whole-mount in situ hybridization shows that $\mathrm{Hg}$ 
and $\mathrm{Pb}$ significantly induce abcc2 expression in the intestine. In contrast, $\mathrm{Cd}$ downregulates abcc 2 expression in the whole embryo. In accordance, qRT-PCR shows abcc2 induction in adult zebrafish exposed to various concentrations of $\mathrm{Hg}$ or $\mathrm{Pb}$ for $24 \mathrm{~h}$, particularly in the intestine, liver, and kidney.

In addition, Long et al. (2011b) have developed fibroblastlike ZF4 cells resistant to toxic metals and arsenic (ZF4-Cd) by chronic exposure to $\mathrm{Cd}$ and selection. ZF4-Cd cells are more resistant to $\mathrm{Cd}, \mathrm{Hg}$, AsIII, and $\mathrm{AsV}$ than the wild-type cell line (ZF4-WT). Besides, ZF4-Cd cells show higher GSH content, abcc2, and abcc4 expression, lower expression of abcc5, and a higher Cd elimination rate than ZF4-WT. Coexposure to metals with ABCC or GST inhibitors drastically reduces both cell types' survival rates.

The results from the three studies by Long et al. (2011a,b,c) indicate the importance of ABCC proteins, GST, and GSH in heavy metals detoxification in different organs, including the intestine in developing and adult zebrafish. Although these studies clearly show that $\mathrm{Abcc} 2$ can transport toxic metals and arsenic toward the external medium in the zebrafish intestine, more results about cell location and polarized transport are necessary to understand the role of intestinal Abcc4 and Abcc5 in fish detoxification processes. For example, in humans and rodent models, ABCC4 localizes to the basolateral membrane of enterocytes and hepatocytes while renal tubules present an apical ABCC4 (Van Aubel et al., 2002; De Waart et al., 2012).

In this sense, exposure to $\mathrm{Pb}$ induces the mRNA and protein expression of abcc4 in zebrafish tissues (the kidney, gills, and intestine) (Lu et al., 2021). These authors detected a concentration-dependent abcc 4 transcripts induction in adult fish exposed to $\mathrm{Pb}$ for $24 \mathrm{~h}$, which was highest in the kidney. Besides, abcc4-/- mutant zebrafish suffered higher mortality and accumulated more $\mathrm{Pb}$ upon exposure to this metal than WT zebrafish. Furthermore, LLC-PK1 cells transfected with zebrafish abcc4 had a higher ability to detoxify and excrete $\mathrm{Pb}$ than the control cells.

A functional experiment with everted and non-everted sacs from rainbow trout middle intestine shows that AsIII enters the enterocytes only from the basolateral side and inhibits the apical DNP-SG transport concentration-dependently. Furthermore, previous in vivo exposure to AsIII increases DNP-SG transport rate and GST activity in middle intestine ex vivo preparations and induces abcc2 RNA expression in the intestine and liver (Painefilú et al., 2019). In the same work, ex vivo intestine preparations from fish previously exposed to AsIII show lower sensitivity to MCLR toxicity than those from control individuals. These results suggest that apical Abcc2 excretes arsenic absorbed either from the intestinal lumen, as AsV and then reduced to AsIII, or from the blood as AsIII. The induction of intestinal Abcc2 enhances the organism's defense against arsenic, and other Abcc2 substrates, like metals and MCLR.

Besides the critical role of Abccs in metals and metalloids detoxification, some studies relate other $\mathrm{ABC}$ proteins to this function, although based only on gene expression data. For example, adult zebrafish exposed to $\mathrm{Hg}$ show upregulated intestine $a b c g 2 b$ together with several genes related to xenobiotic biodegradation, development, and oxidative stress
(Zhang Q.L. et al., 2020). Abcb10, a mitochondrial ABC protein associated with the cellular response to oxidative stress, is significantly upregulated in muscle tissue of zebrafish exposed to $\mathrm{Cu}$ and $\mathrm{Cd}$. Also, abcb10 transcript levels increase in the intestine and other tissues, albeit to a lesser extent (Sabri et al., 2012). Finally, Abcc7 is not a xenobiotic transporter but can be affected by inorganic pollutants. For example, $\mathrm{Hg}$ inhibits the $\mathrm{Cl}$ transport dose-dependently in the shark rectal gland probably by non-competitive interaction with Abcc7 (Ratner et al., 2006; Weber et al., 2006).

\section{Pesticides and Pharmaceuticals}

Cárcamo et al. (2011) exposed rainbow trout to the antiparasitic compound emamectin benzoate (EMB) and analyzed abcb4, abcc1, and CYP enzymes mRNA expression in tissues through semiquantitative RT-PCR. Their results show upregulation of most of the studied CYP and ABC genes after EMB treatment, with the highest increase in kidney and intestine abccl (45and 97-fold, respectively). The expression of abcb4 was downregulated in the intestine and slightly affected in other tissues. Although the cited study does not analyze the possible transport of $\mathrm{EMB}$ by $\mathrm{ABC}$ proteins, it is interesting to notice that, in the intestine, this compound downregulates abcb4 and strongly induces abccl. This effect would reduce the intestinal xenobiotic excretion capacity and increase the EMB transport into the blood, depending on the affinity of Abcc1 for EMB. The marked abcc1 induction in the kidney suggests a possible increase in the glomerular Abccl activity, as reported for streptozocin-treated rats (Quezada et al., 2011), which would facilitate EMB filtration. A recent study by Moraes et al. (2020) shows that glyphosate and a commercial glyphosate formulation (RT) modulate adult zebrafish $\mathrm{ABC}$ expression and activity in a tissue-specific fashion. These authors report that $96 \mathrm{~h}$ exposure to environmentally relevant glyphosate and RT concentrations $\left(0.1 \mathrm{mg} \mathrm{L}^{-1}\right)$ increase the transport activity of the Abcc fluorescent substrate calcein in the intestine and other tissues. This effect is more pronounced in the intestine and gills. In the same study, the expression profiles of five abcc genes differ among tissues. The intestine shows only a modest induction of abcc 3 by RT and downregulation of abccl by glyphosate and RT. In contrast, the gills show a strong induction of abcc2 expression by RT.

These results that suggest various modulation pathways for Abcc activity in different organs are comparable with those from earlier studies on the arsenic effect on Abcc2 transport activity in killifish (Miller et al., 2007; Shaw et al., 2007). The former authors report that AsIII stimulates Abcc2 transport in killifish renal tubules by a non-genomic mechanism, while the latter find induction of abcc2 by AsIII in the liver of the same species. In this sense, De Anna (2019) reports that chlorpyrifos induces the efflux of the ABCC substrate DNP-SG in rainbow trout intestine ex vivo preparations in a concentration-dependent manner. The further study of the polarized transport in everted intestinal sacs exposed to $20 \mu \mathrm{g} \mathrm{L}^{-1}$ chlorpyrifos shows increased DNP-SG transport rate by apical membrane transporters, likely Abcc2, but no change in abcc2 mRNA expression. The fact that chlorpyrifos stimulates DNP-SG transport ex vivo instead of producing a competitive inhibition suggests that chlorpyrifos is not an Abcc2 
substrate. De Anna et al. (2021) report that the exposure of rainbow trout to chlorpyrifos in vivo for $12 \mathrm{~h}$ induces the RNA expression of the nuclear receptor pregnane $\mathrm{X}$ receptor (PXR) in the intestine and liver, together with an induction of abcc 2 only in the intestine but no change in abcb4 expression. In contrast, as described above, AsIII and MCLR are substrates of the rainbow trout intestine $\mathrm{Abcc} 2$ and thus competitively inhibit DNP-SG transport ex vivo, but only AsIII induces intestinal abcc2 mRNA expression after exposure in vivo (Bieczynski et al., 2014, 2016; Painefilú et al., 2019; Painefilú, 2021).

Lu et al. (2014) report that, in 96 hpf zebrafish embryos, abcc4 transcripts appear mainly in the intestine and gills. These authors showed that the overexpression of abcc4 in embryos reduces the mortality rate caused by the organochlorine pesticides DDT and lindane and reduces their accumulation. The expression of a dominant abcc4 mutation has the opposite effects. Accordingly, in the same study, LLC-PK1 cells transfected with the zebrafish abcc4 suffered lower DDT and lindane cytotoxicity than control cells and had higher pesticide transport capacity. Both pesticides also caused abcc4 induction in exposed embryos. The authors propose that Abcc4 is critical for DDT and lindane detoxification.

Zhang L. et al. (2020) reported a dose-dependent induction of abcg 5 and abcg8 in zebrafish larvae exposed to lindane (from 96 to $120 \mathrm{hpf}$ ). Besides, larvae with Abcg5 or Abcg8 overexpression showed a significantly reduced toxicity and lower lindane accumulation than the control larvae. The co-overexpression of both proteins enhanced their protective effects. These authors conclude that Abcg5/8 transport lindane, in addition to the function of Abcc4 in organochlorine pesticides detoxification reported previously by the same group (Lu et al., 2014). Although the results of this study refer to whole larvae without tissue discrimination, the authors state that abcg 5 and abcg 8 are mainly present in the intestine and liver. Since in mammalian intestine and liver, ABCG5/8 are apical membrane proteins while Abcc4 locates to the basolateral membrane in both organs (Graf et al., 2003; De Waart et al., 2012), Abcg5/8 seem more suitable to excrete toxic compounds in both organs than Abcc4.

On the other hand, ABCC4 localizes to the apical membrane in the mammalian kidney tubules. Thus, it would export xenobiotics to urine, conferring resistance to the organism. Therefore, understanding the physiological role of ABC proteins in fish requires new studies on their function and cellular location and the regulatory pathways involved in their expression and trafficking to the membrane in different organs.

Love et al. (2021) studied the basal RNA expression of abcb4 and abcb5 in different tissues of the rainbow trout and their inducibility by the antifungal agent clotrimazole. Abcb4 RNA was expressed ubiquitously among tissues, showing its highest expression in the proximal and distal intestine (followed by the liver and several parts of the central nervous system). This transporter showed three orders of magnitude higher expression than abcb5 in the intestine. The intraperitoneal injection of clotrimazole resulted in a significant induction of abcb5 in the optic lobe and the distal intestine (4.4 and 3.2 fold increase, respectively). Clotrimazole is a potent ligand of the human PXR, and there is evidence of PXR activation following exposure to clotrimazole in fish (Kliewer et al., 2002; Moore et al., 2002;
Milnes et al., 2008; Bainy et al., 2013). However, few studies exist on the expression of potential PXR-target genes in fish, particularly in the intestine. As detailed above, De Anna et al. (2021) reported the induction of PXR and its target genes abcc2 and cyp $2 \mathrm{k} 1$ but not abcb4 by chlorpyrifos in the rainbow trout middle intestine, which corresponds to the rear part of the proximal intestine in the Love et al. (2021) study. Both studies coincide in the lack of induction of abcb4 by PXR agonists, such as clotrimazole and chlorpyrifos, in the rainbow trout anteriormid intestine. In contrast, the abcb5 induction by clotrimazole only in the distal intestine and optic lobe (Love et al., 2021) suggests a tissue-dependent response of this gene. As far as we know, there are no reports on the regulation of abcb5 expression in fish.

\section{Hydrocarbons}

As far as we know, there are no reports on the transport of hydrocarbons or related compounds by $\mathrm{ABC}$ proteins in the fish intestine. Bard et al. (2002) have studied the expression of Pgp protein in different tissues of killifish, collected from relatively unpolluted and polluted sites with high levels of polychlorinated biphenyls (PCB) and planar halogenated aromatic hydrocarbons (PHAHs) by immunohistochemistry and immunoblot techniques with the mAb C219. They localized Pgp in epithelial cells of the posterior intestine, with intense staining in more than half of the individuals collected at the polluted site. In contrast, only 3-6\% of the fish collected at the control site showed a positive Pgp reaction. In contrast, fish livers from the control site had greater Pgp expression than those from the polluted area.

Costa et al. (2012) characterized the sequences of the ABC genes abcb1-like, abcb11, abcc1, abcc2, abcg2. They analyzed the mRNA expression of those genes together with CYP1A and GST $\alpha$ in the liver, gills, and proximal intestine of the Nile tilapia exposed to $\mathrm{BaP}$ dissolved in water or added to the diet. Control fish showed the highest abcb1-like, abcc2, and abcg2 mRNA relative expression in the anterior intestine, followed by the liver. Among the abcc genes, water-born $\mathrm{BaP}$ induced abccl and abcc2 in the gills, together with intestine (concentration-dependent) and liver abcg2. Interestingly, dietary $\mathrm{BaP}$ only induced gill abcc2, while the solvent added to the diet (acetone) induced intestine abcc1 and abcg2. Both treatments induced CYP1A, a known target of the nuclear receptor AhR, with the highest effect on the intestine. There was no significant effect of $\mathrm{BaP}$ in the expression of abcb1like or abcb11. The results on CYP1A and abcb1-like coincide with a further western blot and immunofluorescence study by the same group (Costa et al., 2013) that shows increased protein expression of CYP1A but not Pgp in Nile tilapia exposed to BaP.

\section{DISCUSSION AND FUTURE PERSPECTIVES}

Studies on fish ABC proteins show high functional homology with their human counterparts (Luckenbach et al., 2014, for review; Robey et al., 2021). However, the available evidence on their physiological role in the intestine includes only the 
ABCB, ABCC, and ABCG subfamilies, plus two studies on abca1 and abca2 RNA expression (Kortner et al., 2014; Liu et al., 2016). Toxicological studies show tissue-specific effects (e.g., Bard et al., 2002) and offer clues on the involvement of several regulatory pathways.

Studies on ABCB proteins show high expression of abcb4, especially in the posterior intestine (Lončar et al., 2010; Love et al., 2021). In the rainbow trout, the PXR agonists chlorpyrifos and clotrimazole did not affect intestinal abcb4 expression, while clotrimazole induced abcb5 (De Anna et al., 2021; Love et al., 2021). Among the AhR agonists (related with PCB and hydrocarbons pollution), $\mathrm{BaP}$ did not induce abcbl-like or abcb11 in the Nile tilapia (Costa et al., 2012), while in the channel catfish, $\beta$-naphthoflavone increased the immunohistochemical label intensity with an anti-Pgp antibody (Kleinow et al., 2000). Since the latter paper and other studies on the effects of hydrocarbons and other inducers of the AhR use antimammalian Pgp antibodies that do not discriminate among abcb4, abcb5, and abcb11, the impact of this kind of pollutants on fish intestine $\mathrm{ABCB}$ proteins remains unclear.

ABCC transporters are abundant in the fish intestine, but only Abcc2 is present in the apical membrane. Several reports supply evidence related to the excretion of MCLR and arsenic to the intestinal lumen (Bieczynski et al., 2014, 2016; Painefilú et al., 2019) by Abcc2 or the induction of abcc2, abcc4, and abcc 5 by the exposure to arsenic and toxic metals associated to increased resistance (Long et al., 2011a,b,c; Painefilú et al., 2019). These results suggest a critical role of intestinal Abcc2 as a barrier against a variety of xenobiotics. While the induction of the basolateral proteins, abcc 4 and abcc 5 by metals, indicates metals transport to another detoxification organ. Similarly, the increased intestinal and renal abccl expression by the pharmaceutical emamectin benzoate (Cárcamo et al., 2011) suggests intestinal drug absorption and renal excretion.

Abcg2, Abcg5, and Abcg8 are present in the fish intestine, being Abcg2 particularly abundant. Kortner et al. (2014) report the expression of abcg 5 together with abcal in the Atlantic salmon pyloric ceca, which suggests the participation of both transporters in the regulation of cholesterol uptake and excretion. Zhang L. et al. (2020) and Zhang Q.L. et al. (2020) reported induction of intestinal abcg 5 and $\mathrm{abcg} 8$ associated with resistance to the pesticide lindane and upregulation of abcg2b by $\mathrm{Hg}$ in zebrafish. Costa et al. (2012) reported the induction of intestinal abcg2 in the Nile tilapia in response to BaP.

Besides the few physiological and toxicological works cited in this review, there is a lack of information about the role of $\mathrm{ABC}$ proteins in the physiological functions of the intestine, such as bile compounds secretion and reabsorption and transport of other metabolites. These functions are exciting for the development of new feed ingredients for aquaculture.

Most frequently, polluted environments contain more than one toxic substance or even complex mixes. However, few works deal with the effects of combining xenobiotics on ABC. The studies on the impact of pollutants interaction on these proteins should include traditionally studied ones and others that generate growing concern. For example, microplastics may enter the organism via the gastrointestinal tract and affect ABC-mediated transport. Wu et al. (2019) have reported that polystyrene microplastics inhibit $\mathrm{ABC}$ efflux activity in the human colon adenocarcinoma Caco- 2 cells and could act as chemosensitizers to other pollutants by increasing their intracellular accumulation.

Another factor to consider in future studies on $\mathrm{ABC}$ proteins is the gut microbiome that most likely influences the functions of these transporters. In mammals, the intestinal microbiota metabolizes different drugs and natural metabolites, such as bile salts, also substrates and modulators of ABC proteins. Thus, the intestinal microbiota affects the intestinal absorption and detoxification processes (Klaassen and Cui, 2015, for a review). In fish, there are few studies on microbiome-host toxicokinetic interaction. As far as we know, there are no specific works on the microbiome and $\mathrm{ABC}$ proteins interaction. However, xenobiotics, like antibiotics, other drugs, and microplastics, can affect the microbiome composition and metabolism and, therefore, the intestinal function in general and the function of ABC proteins in particular (see Bertotto et al., 2019; Catron et al., 2019 and citations reviewed therein; Ding et al., 2021).

Inflammation and infection processes are almost wholly unexplored concerning ABC protein functions. Mottaz et al. (2017) suggested that bacterial lipopolysaccharides (LPS), which induce an inflammatory response in zebrafish embryos, are eliminated through ABC proteins. These authors exposed embryos to LPS with/without the Abcb4 inhibitor cyclosporine A and found higher LPS accumulation in the gastrointestinal region of the individuals treated with cyclosporine A. Similarly, Neudeck et al. (2004) found that Pgp (expression and function) affects the invasion capacity of the bacteria Listeria monocytogenes in the Caco2 cell line and other mammalian models.

Future experiments should consider that a great variety of aquatic pollutants, infectious agents, aquaculture feed components, and therapeutic agents can interact with fish intestinal $\mathrm{ABC}$ proteins, affecting their barrier and secretory function. These interactions could be direct or mediated by a change in the microbiome conditions.

\section{AUTHOR CONTRIBUTIONS}

FB and CL designed and wrote the text. JP performed the graphs. JP and AV collaborated in the revision and editing of the manuscript. All the authors contributed to the article and approved the submitted version.

\section{FUNDING}

We acknowledge grants from ANPCYT: PICT 2018-2653 to CL and PICT 2019-649 to FB.

\section{ACKNOWLEDGMENTS}

We thank Till Luckenbach for his helpful comments. We thank Pablo Moreno, Water Torres, Jorge Kuroda (CEAN), and Daniel Painefilú for their technical advice. We also thank the helpful comments of the two reviewers. 


\section{REFERENCES}

Aikawa, T., Holm, M. L., and Kanekiyo, T. (2018). ABCA7 and pathogenic pathways of Alzheimer's disease. Brain Sci. 8, 1-13. doi: 10.3390/brainsci8020027

Alves, A., Gregório, S. F., Egger, R. C., and Fuentes, J. (2019). Molecular and functional regionalization of bicarbonate secretion cascade in the intestine of the European sea bass (Dicentrarchus labrax). Comp. Biochem. Physiol. A Mol. Integr. Physiol. 233, 53-64. doi: 10.1016/j.cbpa.2019.03.017

Amado, L. L., and Monserrat, J. M. (2010). Oxidative stress generation by microcystins in aquatic animals: Why and how. Environ. Int. 36, 226-235. doi: 10.1016/j.envint.2009.10.010

Amsterdam, A., Nissen, R. M., Sun, Z., Swindell, E. C., Farrington, S., and Hopkins, N. (2004). Identification of 315 genes essential for early zebrafish development. Proc. Natl. Acad. Sci. U. S. A. 101, 12792-12797. doi: 10.1073/pnas.0403929101

Ando, M., and Takei, Y. (2015). Guanylin activates $\mathrm{Cl}-$ secretion into the lumen of seawater eel intestine via apical $\mathrm{Cl}$ - channel under simulated in vivo conditions. Am. J. Physiol. - Regul. Integr. Comp. Physiol. 308, R400-R410. doi: 10.1152/ ajpregu.00333.2014

Andrinolo, D., Gomes, P., Fraga, S., Soares-Da-Silva, P., and Lagos, N. (2002a). Transport of the organic cations gonyautoxin $2 / 3$ epimers, a paralytic shellfish poison toxin, through the human and rat intestinal epitheliums. Toxicon 40, 1389-1397. doi: 10.1016/S0041-0101(02)00118-6

Andrinolo, D., Iglesias, V., García, C., and Lagos, N. (2002b). Toxicokinetics and toxicodynamics of gonyautoxins after an oral toxin dose in cats. Toxicon 40, 699-709. doi: 10.1016/S0041-0101(01)00263-X

Annilo, T., Chen, Z. Q., Shulenin, S., Costantino, J., Thomas, L., Lou, H., et al. (2006). Evolution of the vertebrate ABC gene family: Analysis of gene birth and death. Genomics 88, 1-11. doi: 10.1016/j.ygeno.2006.03.001

Bainy, A. C. D., Kubota, A., Goldstone, J. V., Lille-Langøy, R., Karchner, S. I., Celander, M. C., et al. (2013). Functional characterization of a full length pregnane $\mathrm{X}$ receptor, expression in vivo, and identification of PXR alleles, in Zebrafish (Danio rerio). Aquat. Toxicol. 14, 447-457. doi: 10.1016/j.aquatox. 2013.09.014

Baker, A., Carrier, D. J., Schaedler, T., Waterham, H. R., Van Roermund, C. W., and Theodoulou, F. L. (2015). Peroxisomal ABC transporters: Functions and mechanism. Biochem. Soc. Trans. 43, 959-965. doi: 10.1042/BST20150127

Ballatori, N., Rebbeor, J. F., Connolly, G. C., Seward, D. J., Lenth, B., Henson, J. H., et al. (2000). Bile salt excretion in skate liver is mediated by a functional analog of Bsep/Spgp, the bile salt export pump. Am. J. Physiol. Gastrointest. Liver Physiol. 278, 57-63. doi: 10.1152/ajpgi.2000.278.1.G57

Bard, S. M. (2000). Multixenobiotic resistance as a cellular defense mechanism in aquatic organisms. Aquat. Toxicol. 48, 357-389. doi: 10.1016/S0166-445X(00) 00088-6

Bard, S. M., Bello, S. M., Hahn, M. E., and Stegeman, J. J. (2002). Expression of P-glycoprotein in killifish (Fundulus heteroclitus) exposed to environmental xenobiotics. Aquat. Toxicol. 59, 237-251. doi: 10.1016/S0166-445X(01)00256-9

Bertotto, L. B., Catron, T. R., and Tal, T. (2019). Exploring interactions between xenobiotics, microbiota, and neurotoxicity in zebrafish. Neurotoxicology 76, 235-244. doi: 10.1016/j.neuro.2019.11.008

Betancur, R. R., Wiley, E. O., Arratia, G., Acero, A., Bailly, N., Miya, M., et al. (2017). Phylogenetic classification of bony fishes. BMC Evol. Biol. 17:162. doi: 10.1186/s12862-017-0958-3

Bewley, M. S., Pena, J. T. G., Plesch, F. N., Decker, S. E., Weber, G. J., and Forrest, J. N. (2006). Shark rectal gland vasoactive intestinal peptide receptor: Cloning, functional expression, and regulation of CFTR chloride channels. Am. J. Physiol. Regul. Integr. Comp. Physiol. 291, 1157-1164. doi: 10.1152/ajpregu.00078.2006

Bieczynski, F., Bianchi, V. A., and Luquet, C. M. (2013). Accumulation and biochemical effects of microcystin-LR on the Patagonian pejerrey (Odontesthes hatcheri) fed with the toxic cyanobacteria Microcystis aeruginosa. Fish Physiol. Biochem. 39, 1309-1321. doi: 10.1007/s10695-013-9785-7

Bieczynski, F., Burkhardt-Medicke, K., Luquet, C. M., Scholz, S., and Luckenbach, T. (2021). Chemical effects on dye efflux activity in live zebrafish embryos and on zebrafish Abcb4 ATPase activity. FEBS Lett. 595, 828-843. doi: 10.1002/ 1873-3468.14015

Bieczynski, F., De Anna, J. S., Pirez, M., Brena, B. M., Villanueva, S. S. M., and Luquet, C. M. (2014). Cellular transport of microcystin-LR in rainbow trout (Oncorhynchus mykiss) across the intestinal wall: Possible involvement of multidrug resistance-associated proteins. Aquat. Toxicol. 154, 97-106. doi: 10.1016/j.aquatox.2014.05.003

Bieczynski, F., Torres, W. D. C., Painefilu, J. C., Castro, J. M., Bianchi, V. A., Frontera, J. L., et al. (2016). Alterations in the intestine of Patagonian silverside (Odontesthes hatcheri) exposed to microcystin-LR: Changes in the glycosylation pattern of the intestinal wall and inhibition of multidrug resistance proteins efflux activity. Aquat. Toxicol. 178, 106-117. doi: 10.1016/ j.aquatox.2016.07.016

Boaru, D. A., Dragoş, N., and Schirmer, K. (2006). Microcystin-LR induced cellular effects in mammalian and fish primary hepatocyte cultures and cell lines: A comparative study. Toxicology 218, 134-148. doi: 10.1016/j.tox.2005.10.005

Bodinier, C., Boulo, V., Lorin-Nebel, C., and Charmantier, G. (2009a). Influence of salinity on the localization and expression of the CFTR chloride channel in the ionocytes of Dicentrarchus labrax during ontogeny. J. Anat. 214, 318-329. doi: 10.1111/j.1469-7580.2009.01050.x

Bodinier, C., Lorin-Nebel, C., Charmantier, G., and Boulo, V. (2009b). Influence of salinity on the localization and expression of the CFTR chloride channel in the ionocytes of juvenile Dicentrarchus labrax exposed to seawater and freshwater. Comp. Biochem. Physiol. A Mol. Integr. Physiol. 153, 345-351. doi: 10.1016/j.cbpa.2009.03.011

Borst, P. (2020). Looking back at multidrug resistance (MDR) research and ten mistakes to be avoided when writing about $\mathrm{ABC}$ transporters in MDR. FEBS Lett. 594, 4001-4011. doi: 10.1002/1873-3468.13972

Boswell-Casteel, R. C., Fukuda, Y., and Schuetz, J. D. (2017). ABCB6, an ABC Transporter Impacting Drug Response and Disease. AAPS J. 20:8. doi: 10.1208/ s12248-017-0165-6

Boyer, J. L., and Soroka, C. J. (2021). Bile formation and secretion: An update. J. Hepatol. 75, 190-201. doi: 10.1016/j.jhep.2021.02.011

Brugman, S. (2016). The zebrafish as a model to study intestinal inflammation. Dev. Comp. Immunol. 64, 82-92. doi: 10.1016/j.dci.2016.02.020

Brunham, L. R., Kruit, J. K., Iqbal, J., Fievet, C., Timmins, J. M., Pape, T. D., et al. (2006). Intestinal ABCA1 directly contributes to HDL biogenesis in vivo. J. Clin. Invest. 116, 1052-1062. doi: 10.1172/JCI27352

Bury, N. R., Newlands, A. D., Eddy, F. B., and Codd, G. A. (1998). In vivo and in vitro intestinal transport of $3 \mathrm{H}$-microcystin-LR, a cyanobacterial toxin, in rainbow trout (Oncorhynchus mykiss). Aquat. Toxicol. 42, 139-148. doi: 10. 1016/S0166-445X(98)00041-1

Cai, S. Y., Soroka, C. J., Ballatori, N., and Boyer, J. L. (2003). Molecular characterization of a multidrug resistance-associated protein, Mrp2, from the little skate. Am. J. Physiol. Regul. Integr. Comp. Physiol. 284, 125-130. doi: 10.1152/ajpregu.00392.2002

Cameron, J. S., DeWitt, J. P., Ngo, T. T., Yajnik, T., Chan, S., Chung, E., et al. (2013). Cardiac KATP channel alterations associated with acclimation to hypoxia in goldfish (Carassius auratus L.). Comp. Biochem. Physiol. A Mol. Integr. Physiol. 164, 554-564. doi: 10.1016/j.cbpa.2012.12.020

Caminada, D., Zaja, R., Smital, T., and Fent, K. (2008). Human pharmaceuticals modulate P-gp1 (ABCB1) transport activity inthe fish cell line PLHC-1. Aquat. Toxicol. 90, 214-222. doi: 10.1016/j.aquatox.2008. 08.013

Cárcamo, J. G., Aguilar, M. N., Barrientos, C. A., Carreño, C. F., Quezada, C. A., Bustos, C., et al. (2011). Effect of emamectin benzoate on transcriptional expression of cytochromes P450 and the multidrug transporters (Pgp and MRP1) in rainbow trout (Oncorhynchus mykiss) and the sea lice Caligus rogercresseyi. Aquaculture 321, 207-215. doi: 10.1016/j.aquaculture.2011.09. 012

Carmichael, W. W. (1994). The toxins of cyanobacteria. Sci. Am. 270, 78-86. doi: 10.1038/scientificamerican0194-78

Castro, L. F. C., Gonçalves, O., Mazan, S., Tay, B. H., Venkatesh, B., and Wilson, J. M. (2013). Recurrent gene loss correlates with the evolution of stomach phenotypes in gnathostome history. Proc. R. Soc. B Biol. Sci. 281:20132669. doi: 10.1098/rspb.2013.2669

Catron, T. R., Gaballah, S., and Tal, T. (2019). Using Zebrafish to Investigate Interactions Between Xenobiotics and Microbiota. Curr. Pharmacol. Rep. 5, 468-480. doi: 10.1007/s40495-019-00203-7

Chan, K. M., Davies, P. L., Childs, S., Veinot, L., and Ling, V. (1992). P-glycoprotein genes in the winter flounder, Pleuronectes americanus: Isolation of two types of genomic clones carrying $3^{\prime}$ terminal exons. BBA Gene Struct. Expr. 1171, 65-72. doi: 10.1016/0167-4781(92)90140-U 
Chan, L. M. S., Lowes, S., and Hirst, B. H. (2004). The ABCs of drug transport in intestine and liver: Efflux proteins limiting drug absorption and bioavailability. Eur. J. Pharm. Sci. 21, 25-51. doi: 10.1016/j.ejps.2003.07.003

Chen, K. G., Szakács, G., Annereau, J. P., Rouzaud, F., Liang, X. J., Valencia, J. C., et al. (2005). Principal expression of two mRNA isoforms (ABCB5 $\alpha$ and $\mathrm{ABCB} 5 \beta)$ of the ATP-binding cassette transporter gene ABCB5 in melanoma cells and melanocytes. Pigment Cell Res. 18, 102-112. doi: 10.1111/j.1600-0749. 2005.00214.x

Choi, Y. M., Kim, Y. Il, Choi, J. H., Bhandari, S., Nam, I. K., Hong, K. H., et al. (2019). Loss of abcd4 in zebrafish leads to vitamin B12-deficiency anemia. Biochem. Biophys. Res. Commun. 514, 1264-1269. doi: 10.1016/j.bbrc.2019.05. 099

Chorus, I., and Bartram, J. (1999). Toxic Cyanobacteria: a Guide to Their Public Health Consequences, Monitoring and Management. New York: WHO.

Cooper, P. S. (1996). Expression of the Xenobiotic Transporter P-glycoprotein in the Mummichog (Fundulus heteroclitus). United States: Virginia Institute of Marine Science. doi: 10.25773/v5-afeh-j139

Costa, J., Reis-Henriques, M. A., Castro, L. F. C., and Ferreira, M. (2012). Gene expression analysis of ABC efflux transporters, CYP1A and GST $\alpha$ in Nile tilapia after exposure to benzo(a)pyrene. Comp. Biochem. Physiol. C Toxicol. Pharmacol. 155, 469-482. doi: 10.1016/j.cbpc.2011.12.004

Costa, J., Reis-Henriques, M. A., Wilson, J. M., and Ferreira, M. (2013). P-glycoprotein and CYP1A protein expression patterns in Nile tilapia (Oreochromis niloticus) tissues after waterborne exposure to benzo(a)pyrene (BaP). Environ. Toxicol. Pharmacol. 36, 611-625. doi: 10.1016/j.etap.2013.05. 017

Cremers, F. P. M., Lee, W., Collin, R. W. J., and Allikmets, R. (2020). Clinical spectrum, genetic complexity and therapeutic approaches for retinal disease caused by ABCA4 mutations. Prog. Retin. Eye Res. 79:100861. doi: 10.1016/j. preteyeres.2020.100861

Cui, G., Hong, J., Chung-Davidson, Y. W., Infield, D., Xu, X., Li, J., et al. (2019). An Ancient CFTR Ortholog Informs Molecular Evolution in ABC Transporters. Dev. Cell 51, 421.e-430.e. doi: 10.1016/j.devcel.2019. 09.017

Dassa, E. (2003). "Phylogenetic and functional classification of ABC (ATP-binding cassette) systems" in ABC Proteins From Bacteria To Man. eds I. B. Holland, S. P. C. Cole, K. Kuchler, and C. F. B. T. Higgins (London: Academic Press). 3-35.

De Anna, J. (2019). Efectos de la Interacción Entre Compuestos Tóxicos en Trucha Arcoí ris (Oncorhynchus Mykiss). San Carlos de Bariloche: Universidad Nacional del Comahue.

De Anna, J. S., Darraz, L. A., Painefilú, J. C., Cárcamo, J. G., Moura-Alves, P., Venturino, A., et al. (2021). The insecticide chlorpyrifos modifies the expression of genes involved in the PXR and AhR pathways in the rainbow trout, Oncorhynchus mykiss. Pestic. Biochem. Physiol. 178:104920. doi: 10.1016/ j.pestbp.2021.104920

De Jonge, H. R., Tilly, B. C., Hogema, B. M., Pfau, D. J., Kelley, C. A., Kelley, M. H., et al. (2014). cGMP inhibition of type 3 phosphodiesterase is the major mechanism by which C-type natriuretic peptide activates CFTR in the shark rectal gland. Am. J. Physiol. Cell Physiol. 306, C343-C353. doi: 10.1152/ajpcell. 00326.2013

De Waart, D. R., Van De Wetering, K., Kunne, C., Duijst, S., Paulusma, C. C., and Oude Elferink, R. P. J. (2012). Oral availability of cefadroxil depends on ABCC3 and ABCC4. Drug Metab. Dispos. 40, 515-521. doi: 10.1124/dmd.111.041731

Dean, M., and Annilo, T. (2005). Evolution of the ATP-binding cassette (ABC) transporter superfamily in vertebrates. Annu. Rev. Genomics Hum. Genet. 6, 123-142. doi: 10.1146/annurev.genom.6.080604.162122

Dean, M., Rzhetsky, A., and Allikmets, R. (2001). The Human ATP-Binding Cassette (ABC) Transporter Superfamily. 4, 1156-1166. doi: 10.1101/gr.184901. The

Dermauw, W., and Van Leeuwen, T. (2014). The ABC gene family in arthropods: Comparative genomics and role ininsecticide transport and resistance. Insect Biochem. Mol. Biol. 45, 89-110. doi: 10.1016/j.ibmb.2013. 11.001

Ding, W., Shangguan, Y., Zhu, Y., Sultan, Y., Feng, Y., Zhang, B., et al. (2021). Negative impacts of microcystin-LR and glyphosate on zebrafish intestine: Linked with gut microbiota and microRNAs? Environ. Pollut. 286:117685. doi: 10.1016/j.envpol.2021.117685
Doi, A. M., Holmes, E., and Kleinow, K. M. (2001). P-glycoprotein in the Catfish Intestine: Inducibility by Xenobiotics and Functional Properties. Aquat Toxicol. 55, 57-70.

Ellis, J. L., Bove, K. E., Schuetz, E. G., Leino, D., Valencia, C. A., Schuetz, J. D., et al. (2018). Zebrafish abcbl1b mutant reveals novel strategies to restore bile excretion impaired by bile salt export pump deficiency. Hepatology 67, 1531-1545. doi: 10.1002/hep. 29632

Evans, D. H. (2010). A brief history of the study of fish osmoregulation: The central role of the Mt. Desert Island biological laboratory. Front. Physiol. 1:13. doi: 10.3389/fphys.2010.00013

Fang, L., Choi, S.-H., Baek, J. S., Liu, C., Almazan, F., Ulrich, F., et al. (2013). Control of Angiogenesis by AIBP-mediated cholesterol efflux. Nature 498, 118-122. doi: 10.1038/nature12166

Fang, L., Liu, C., and Miller, Y. I. (2014). Zebrafish models of dyslipidemia: Relevance to atherosclerosis and angiogenesis. Transl. Res. 163, 99-108. doi: 10.1016/j.trsl.2013.09.004

Ferrão-Filho, A., da, S., Kozlowsky-Suzuki, B., and Azevedo, S. M. F. O. (2002). Accumulation of microcystins by a tropical zooplankton community. Aquat. Toxicol. 59, 201-208. doi: 10.1016/S0166-445X(01)00253-3

Ferreira, M., Costa, J., and Reis-Henriques, M. A. (2014). ABC transporters in fish species: A review. Front. Physiol. 5:266. doi: 10.3389/fphys.2014.00266

Feurstein, D., Kleinteich, J., Heussner, A. H., Stemmer, K., and Dietrich, D. R. (2010). Investigation of microcystin congener-dependent uptake into primary murine neurons. Environ. Health Perspect. 118, 1370-1375. doi: 10.1289/ehp. 0901289

Figueira-Mansur, J., Schrago, C. G., Salles, T. S., Alvarenga, E. S. L., Vasconcellos, B. M., Melo, A. C. A., et al. (2020). Phylogenetic analysis of the ATP-binding cassette proteins suggests a new $\mathrm{ABC}$ protein subfamily $\mathrm{J}$ in Aedes aegypti (Diptera: Culicidae). BMC Genomics 21:463. doi: 10.1186/s12864-020-06873-8

Fischer, S., Klüver, N., Burkhardt-Medicke, K., Pietsch, M., Schmidt, A. M., Wellner, P., et al. (2013). Abcb4 acts as multixenobiotic transporter and active barrier against chemical uptake in zebrafish (Danio rerio) embryos. BMC Biol. 11:69. doi: 10.1186/1741-7007-11-69

Fischer, S., Loncar, J., Zaja, R., Schnell, S., Schirmer, K., Smital, T., et al. (2011). Constitutive mRNA expression and protein activity levels of nine ABC efflux transporters in seven permanent cell lines derived from different tissues of rainbow trout (Oncorhynchus mykiss). Aquat. Toxicol. 101, 438-446. doi: 10. 1016/j.aquatox.2010.11.010

Fischer, W. J., Altheimer, S., Cattori, V., Meier, P. J., Dietrich, D. R., and Hagenbuch, B. (2005). Organic anion transporting polypeptides expressed in liver and brain mediate uptake of microcystin. Toxicol. Appl. Pharmacol. 203, 257-263. doi: 10.1016/j.taap.2004.08.012

Forrest, J. N. (2016). the Shark Rectal Gland Model: a Champion of Receptor Mediated Chloride Secretion Through Cftr. Trans. Am. Clin. Climatol. Assoc. $127,162-175$.

Fu, Y., Hsiao, J. H. T., Paxinos, G., Halliday, G. M., and Kim, W. S. (2015). ABCA5 Regulates amyloid- $\beta$ peptide production and is associated with Alzheimer's disease neuropathology. J. Alzheimers Dis. 43, 857-869. doi: 10.3233/JAD141320

García, C., Barriga, A., Díaz, J. C., Lagos, M., and Lagos, N. (2010). Route of metabolization and detoxication of paralytic shellfish toxins in humans. Toxicon 55, 135-144. doi: 10.1016/j.toxicon.2009.07.018

García, C., Bravo, M. D. C., Lagos, M., and Lagos, N. (2004). Paralytic shellfish poisoning: Post-mortem analysis of tissue and body fluid samples from human victims in the Patagonia fjords. Toxicon 43, 149-158. doi: 10.1016/j.toxicon. 2003.11.018

Gessner, B. D., Bell, P., Doucette, G. J., Moczydlowski, E., Poli, M. A., Van Dolah, F., et al. (1997). Hypertension and identification of toxin in human urine and serum following a cluster of mussel-associated paralytic shellfish poisoning outbreaks. Toxicon 35, 711-722. doi: 10.1016/S0041-0101(96)00154-7

Gordon, W. E., Espinoza, J. A., Leerberg, D. M., Yelon, D., and Hamdoun, A. (2019). Xenobiotic transporter activity in zebrafish embryo ionocytes. Aquat. Toxicol. 212, 88-97. doi: 10.1016/j.aquatox.2019.04.013

Gottesman, M. M., Pastan, I., and Ambudkar, S. V. (1996). P-glycoprotein and multidrug resistance. Curr. Opin. Genet. Dev. 6, 610-617. doi: 10.1016/S0959437X(96)80091-8

Graf, G. A., Yu, L., Li, W. P., Gerard, R., Tuma, P. L., Cohen, J. C., et al. (2003). ABCG5 and ABCG8 Are Obligate Heterodimers for Protein Trafficking and 
Biliary Cholesterol Excretion. J. Biol. Chem. 278, 48275-48282. doi: 10.1074/ jbc.M310223200

Gregório, S. F., Carvalho, E. S. M., Encarnação, S., Wilson, J. M., Power, D. M., Canário, A. V. M., et al. (2013). Adaptation to different salinities exposes functional specialization in the intestine of the sea bream (Sparus aurata L.). J. Exp. Biol. 216, 470-479. doi: 10.1242/jeb.073742

Gros, P., Croop, J., and Housman, D. (1986). Mammalian multidrug resistance gene: Complete cDNA sequence indicates strong homology to bacterial transport proteins. Cell 47, 371-380. doi: 10.1016/0092-8674(86)90594-5

Grosell, M. (2006). Intestinal anion exchange in marine fish osmoregulation. J. Exp. Biol. 209, 2813-2827. doi: 10.1242/jeb.02345

Grosell, M. (2011). Intestinal anion exchange in marine teleosts is involved in osmoregulation and contributes to the oceanic inorganic carbon cycle. Acta Physiol. 202, 421-434. doi: 10.1111/j.1748-1716.2010.02241.x

Grosell, M., Farrell, A. P., and Brauner, C. J. (2011). The Multifunctional Gut of Fish. 1st ed. USA: Elsevier. doi: 10.1016/S1546-5098(10)03014-1.

He, S.-M., Li, R., Kanwar, J. R., and Zhou, S.-F. (2011). Structural and Functional Properties of Human Multidrug Resistance Protein 1 (MRP1/ABCC1). Curr. Med. Chem. 18, 439-481. doi: 10.2174/092986711794839197

Hedditch, E. L., Gao, B., Russell, A. J., Lu, Y., Emmanuel, C., Beesley, J., et al. (2014). ABCA transporter gene expression and poor outcome in epithelial ovarian cancer. J. Natl. Cancer Inst. 106:dju149. doi: 10.1093/jnci/dju149

Hemmer, M. J., Courtney, L. A., and Ortego, L. S. (1995). Immunohistochemical detection of P-glycoprotein in teleost tissues using mammalian polyclonal and monoclonal antibodies. J. Exp. Zool. 272, 69-77. doi: 10.1002/jez.1402720109

Hinz, A., and Tampé, R. (2012). ABC transporters and immunity: Mechanism of self-defense. Biochemistry 51, 4981-4989. doi: 10.1021/bi300128f

Holland, B., Cole, S. P. C., Kuchler, K., and Higgins, C. F. (2003). "ABC Proteins" in From Bacteria to Man. eds B. Holland, S. P. C. Cole, K. Kuchler, and C. F. Higgins (London: Academic Press). doi: 10.1016/B978-0-12-352551-2.X5 000-8

Huang, I. S., and Zimba, P. V. (2019). Cyanobacterial bioactive metabolites-A review of their chemistry and biology. Harmful Algae 83, 42-94. doi: 10.1016/j. hal.2018.11.008

Huisman, J., Codd, G. A., Paerl, H. W., Ibelings, B. W., Verspagen, J. M. H., and Visser, P. M. (2018). Cyanobacterial blooms. Nat. Rev. Microbiol. 16, 471-483. doi: 10.1038/s41579-018-0040-1

Jeong, C. B., Kim, B. M., Kang, H. M., Choi, I. Y., Rhee, J. S., and Lee, J. S. (2015). Marine medaka ATP-binding cassette (ABC) superfamily and new insight into teleost Abch nomenclature. Sci. Rep. 5:15409. doi: 10.1038/srep15409

Kala, S. V., Neely, M. W., Kala, G., Prater, C. I., Atwood, D. W., Rice, J. S., et al. (2000). The MRP2/cMOAT transporter and arsenic-glutathione complex formation are required for biliary excretion of arsenic. J. Biol. Chem. 275, 33404-33408. doi: 10.1074/jbc.M007030200

Kamalam, B. S., Rajesh, M., and Kaushik, S. (2020). "Chapter 12: Nutrition and Feeding of Rainbow Trout (Oncorhynchusmykiss). 1st ed" in Fish Nutrition and Its Relevance to Human Health. eds A. S. Ninawe, J. R. Dhanze, R. Dhanze, and S. T. Indulkar. (London: CRC Press). doi: 10.1201/9781003107583-12

Kaur, G., Fahrner, R., Wittmann, V., Stieger, B., and Dietrich, D. R. (2019). Human MRP2 exports MC-LR but not the glutathione conjugate. Chem. Biol. Interact. 311:108761. doi: 10.1016/j.cbi.2019.108761

Kerr, I. D., Hutchison, E., Gerard, L., Aleidi, S. M., and Gelissen, I. C. (2021). Mammalian ABCG-transporters, sterols and lipids: To bind perchance to transport? Biochim. Biophys. Acta Mol. Cell Biol. Lipids 1866:158860. doi: 10. 1016/j.bbalip.2020.158860

Kinne, R., Spokes, K. C., and Silva, P. (2020). Sugar uptake, metabolism, and chloride secretion in the rectal gland of the spiny dogfish Squalus acanthias. Am. J. Physiol. Regul. Integr. Comp. Physiol. 319, 96-105. doi: 10.1152/ajpregu. 00060.2020

Klaassen, C. D., and Aleksunes, L. M. (2010). Xenobiotic, Bile Acid, and Cholesterol Transporters. Pharmacol. Rev. 62, 1-96. doi: 10.1124/pr.109.002014.1

Klaassen, C. D., and Cui, J. Y. (2015). Review: Mechanisms of How the Intestinal Microbiota Alters the Effects of Drugs and Bile Acids. Drug Metab. Dispos. 43, $1505-1521$.

Kleinow, K. M., Doi, A. M., and Smith, A. A. (2000). Distribution and inducibility of P-glycoprotein in the catfish: Immunohistochemical detection using the mammalian C-219 monoclonal. Mar. Environ. Res. 50, 313-317. doi: 10.1016/ S0141-1136(00)00116-1
Kliewer, S. A., Goodwin, B., and Willson, T. M. (2002). The nuclear pregnane X receptor: A key regulator of xenobiotic metabolism. Endocr. Rev. 23, 687-702. doi: 10.1210/er.2001-0038

Klobučar, R. S., Žaja, R., Franjević, D., Brozović, A., and Smital, T. (2010). Presence of ecotoxicologically relevant Pgp and MRP transcripts and proteins in cyprinid fish. Arh. Hig. Rada Toksikol. 61, 175-182. doi: 10.2478/10004-1254-61-20102008

Kobayashi, I., Saito, K., Moritomo, T., Araki, K., Takizawa, F., and Nakanishi, T. (2008). Characterization and localization of side population (SP) cells in zebrafish kidney hematopoietic tissue. Blood 111, 1131-1137. doi: 10.1182/ blood-2007-08-104299

Koelz, H. R. (1992). Gastric acid in vertebrates. Scand. J. Gastroenterol. 27, 2-6. doi: $10.3109 / 00365529209095998$

Kortner, T. M., Björkhem, I., Krasnov, A., Timmerhaus, G., and Krogdahl, ^̊ (2014). Dietary cholesterol supplementation to a plant-based diet suppresses the complete pathway of cholesterol synthesis and induces bile acid production in Atlantic salmon (Salmo salar L.). Br. J. Nutr. 111, 2089-2103. doi: 10.1017/ S0007114514000373

Kropf, C., Fent, K., Fischer, S., Casanova, A., and Segner, H. (2020). ABC transporters in gills of rainbow trout (Oncorhynchus mykiss). J. Exp. Biol. 223:jeb221069. doi: 10.1242/jeb.221069

Kropf, C., Segner, H., and Fent, K. (2016). ABC transporters and xenobiotic defense systems in early life stages of rainbow trout (Oncorhynchus mykiss). Comp. Biochem. Physiol. C Toxicol. Pharmacol. 185-186, 45-56. doi: 10.1016/j.cbpc. 2016.02.006

Kruh, G. D., Guo, Y., Hopper-Borge, E., Belinsky, M. G., and Chen, Z. S. (2007). ABCC10. ABCC11, and ABCC12. Pflugers Arch. Eur. J. Physiol. 453, 675-684. doi: 10.1007/s00424-006-0114-1

Kurelec, B. (1992). The multixenobiotic resistance mechanism in aquatic organisms. Crit. Rev. Toxicol. 22, 23-43. doi: 10.3109/10408449209145320

Lagos, N. (2003). Paralytic shellfish poisoning phycotoxins: Occurrence in South America. Comments Toxicol. 9, 175-193. doi: 10.1080/08865140302429

Lehrich, R. W., Aller, S. G., Webster, P., Marino, C. R., and Forrest, J. N. (1998). Vasoactive intestinal peptide, forskolin, and genistein increase apical CFTR trafficking in the rectal gland of the spiny dogfish, Squalus acanthias: Acute regulation of CFTR trafficking in an intact epithelium. J. Clin. Invest. 101, 737-745. doi: 10.1172/JCI803

Lerebours, A., To, V. V., and Bourdineaud, J. P. (2016). Danio rerio ABC transporter genes abcb3 and abcb7 play a protecting role against metal contamination. J. Appl. Toxicol. 36, 1551-1557. doi: 10.1002/jat.3313

Li, Z., Lui, E. Y., Wilson, J. M., Ip, Y. K., Lin, Q., Lam, T. J., et al. (2014). Expression of key ion transporters in the gill and esophageal- gastrointestinal tract of euryhaline mozambique tilapia oreochromis mossambicus acclimated to fresh water, seawater and hypersaline water. PLoS One 9:e87591. doi: 10.1371/journal. pone.0087591

Lim, L. W. K., Chung, H. H., Ishak, S. D., and Waiho, K. (2021). Zebrafish (Danio rerio) ecotoxicological $\mathrm{ABCB} 4, \mathrm{ABCC} 1$ and $\mathrm{ABCG} 2 \mathrm{a}$ gene promoters depict spatiotemporal xenobiotic multidrug resistance properties against environmental pollutants. Gene Rep. 23:101110. doi: 10.1016/j.genrep.2021. 101110

Liu, S., Li, Q., and Liu, Z. (2013). Genome-Wide Identification, Characterization and Phylogenetic Analysis of 50 Catfish ATP-Binding Cassette (ABC) Transporter Genes. PLoS One 8:e63895. doi: 10.1371/journal.pone.0063895

Liu, X., Li, S., Peng, W., Feng, S., Feng, J., Mahboob, S., et al. (2016). Genomewide identification, characterization and Phylogenetic analysis of ATP-binding cassette $(\mathrm{ABC})$ transporter genes in common carp (cyprinus carpio). PLoS One 11:e0153246. doi: 10.1371/journal.pone.0153246

Lončar, J., Popović, M., Zaja, R., and Smital, T. (2010). Gene expression analysis of the ABC efflux transporters in rainbow trout (Oncorhynchus mykiss). Comp. Biochem. Physiol. C Toxicol. Pharmacol. 151, 209-215. doi: 10.1016/j.cbpc.2009. 10.009

Long, Y., Li, Q., Li, J., and Cui, Z. (2011a). Molecular analysis, developmental function and heavy metal-induced expression of ABCC5 in zebrafish. Comp. Biochem. Physiol. - B Biochem. Mol. Biol. 158, 46-55. doi: 10.1016/j.cbpb.2010. 09.005

Long, Y., Li, Q., Wang, Y., and Cui, Z. (2011b). MRP proteins as potential mediators of heavy metal resistance in zebrafish cells. Comp. Biochem. Physiol. C Toxicol. Pharmacol. 153, 310-317. doi: 10.1016/j.cbpc.2010.12.001 
Long, Y., Li, Q., Zhong, S., Wang, Y., and Cui, Z. (2011c). Molecular characterization and functions of zebrafish $\mathrm{ABCC} 2$ in cellular efflux of heavy metals. Comp. Biochem. Physiol. C Toxicol. Pharmacol. 153, 381-391. doi: 10. 1016/j.cbpc.2011.01.002

Love, R. C., Osachoff, H. L., and Kennedy, C. J. (2021). Short communication: tissue-specific transcript expression of P-glycoprotein isoforms abcbla and abcblb in rainbow trout (Oncorhynchus mykiss) following induction with clotrimazole. Comp. Biochem. Physiol. B 252, 1-5. doi: 10.1016/j.cbpb.2020. 110538

Lu, X., Long, Y., Li, X., Zhang, L., Li, Q., Wen, H., et al. (2021). Generation of knockout and transgenic Zebrafish to characterize abcc4 functions in detoxification and efflux of lead. Int. J. Mol. Sci. 22, 1-18. doi: 10.3390/ ijms22042054

Lu, X., Long, Y., Lin, L., Sun, R., Zhong, S., and Cui, Z. (2014). Characterization of zebrafish Abcc4 as an efflux transporter of organochlorine pesticides. PLoS One 9:e111664. doi: 10.1371/journal.pone.0111664

Lu, X., Long, Y., Sun, R., Zhou, B., Lin, L., Zhong, S., et al. (2015). Zebrafish Abcb4 is a potential efflux transporter of microcystin-LR. Comp. Biochem. Physiol. C Toxicol. Pharmacol. 167, 35-42. doi: 10.1016/j.cbpc.2014.08.005

Luckenbach, T., Fischer, S., and Sturm, A. (2014). Current advances on ABC drug transporters in fish. Comp. Biochem. Physiol. C Toxicol. Pharmacol. 165, 28-52. doi: 10.1016/j.cbpc.2014.05.002

MacKintosh, C., Beattie, K. A., Klumpp, S., Cohen, P., and Codd, G. A. (1990). Cyanobacterial microcystin-LR is a potent and specific inhibitor of protein phosphatases 1 and 2A from both mammals and higher plants. FEBS Lett. 264, 187-192. doi: 10.1016/0014-5793(90)80245-E

Marshall, J., Martin, K. A., Picciotto, M., Hockfield, S., Nairn, A. C., and Kaczmarek, L. K. (1991). Identification and localization of a dogfish homolog of human cystic fibrosis transmembrane conductance regulator. J. Biol. Chem. 266, 22749-22754. doi: 10.1016/s0021-9258(18)54631-7

Marshall, W. S., Cozzi, R. R. F., Pelis, R. M., and Mccormick, S. D. (2005). Cortisol receptor blockade and seawater adaptation in the euryhaline teleost Fundulus heteroclitus. J. Exp. Zool. Part A Comp. Exp. Biol. 303, 132-142. doi: 10.1002/ jez.a.129

Marshall, W. S., Howard, J. A., Cozzi, R. R. F., and Lynch, E. M. (2002). $\mathrm{NaCl}$ and fluid secretion by the intestine of the teleost Fundulus heteroclitus: Involvement of CFTR. J. Exp. Biol. 205, 745-758. doi: 10.1242/jeb.205.6.745

Marshall, W. S., Watters, K. D., Hovdestad, L. R., Cozzi, R. R. F., and Katoh, F. (2009). CFTR Cl- channel functional regulation by phosphorylation of focal adhesion kinase at tyrosine 407 in osmosensitive ion transporting mitochondria rich cells of euryhaline killifish. J. Exp. Biol. 212, 2365-2377. doi: 10.1242/jeb. 030015

Masereeuw, R., Terlouw, S. A., Van Aubel, R. A. M. H., Russel, F. G. M., and Miller, D. S. (2000). Endothelin B receptor-mediated regulation of ATP-driven drug secretion in renal proximal tubule. Mol. Pharmacol. 57, 59-67.

Matsumoto, T., Kitajima, S., Yamamoto, C., Aoyagi, M., Mitoma, Y., Harada, H., et al. (2020). Cloning and tissue distribution of the ATP-binding cassette subfamily G member 2 gene in the marine pufferfish Takifugu rubripes. Fish. Sci. 86, 873-887. doi: 10.1007/s12562-020-01451-z

Meng, X., Clews, J., Martin, E. R., Ciuta, A. D., and Ford, R. C. (2018). The structural basis of cystic fibrosis. Biochem. Soc. Trans. 46, 1093-1098. doi: 10.1042/BST20180296

Mikalsen, S. O., Kongsstovu, S., and Tausen, M. (2021). Connexins during 500 million years-from cyclostomes to mammals. Int. J. Mol. Sci. 22, 1-21. doi: 10.3390/ijms22041584

Miller, D. S. (1995). Daunomycin secretion by killifish renal proximal tubules. Am. J. Physiol. Regul. Integr. Comp. Physiol. 269, 370-379.

Miller, D. S., Masereeuw, R., and Karnaky, K. J. (2002). Regulation of MRP2mediated transport in shark rectal salt gland tubules. Am. J. Physiol. Regul. Integr. Comp. Physiol. 282, R774-81. doi: 10.1152/ajpregu.00333.2001

Miller, D. S., Masereeuw, R., Henson, J., and Karnaky, K. J. (1998). Excretory transport of xenobiotics by dogfish shark rectal gland tubules. Am. J. Physiol. Regul. Integr. Comp. Physiol. 275, R697-705. doi: 10.1152/ajpregu.1998.275.3. r697

Miller, D. S., Shaw, J. R., Stanton, C. R., Barnaby, R., Karlson, K. H., Hamilton, J. W., et al. (2007). MRP2 and acquired tolerance to inorganic arsenic in the kidney of killifish (Fundulus heteroclitus). Toxicol. Sci. 97, 103-110. doi: 10.1093/toxsci/ $\mathrm{kfm} 030$
Milnes, M. R., Garcia, A., Grossman, E., Grün, F., Shiotsugu, J., Tabb, M. M., et al. (2008). Activation of steroid and xenobiotic receptor (SXR, NR1/2) and its orthologs in laboratory, toxicologic, and genome model species. Environ. Health Perspect. 116, 880-885. doi: 10.1289/ehp.10853

Miyake, A., Higashijima, S. I., Kobayashi, D., Narita, T., Jindo, T., Setiamarga, D. H. E., et al. (2008). Mutation in the abcb7 gene causes abnormal iron and fatty acid metabolism in developing medaka fish. Dev. Growth Differ. 50, 703-716. doi: 10.1111/j.1440-169X.2008.01068.x

Moore, L. B., Maglich, J. M., McKee, D. D., Wisely, B., Willson, T. M., Kliewer, S. A., et al. (2002). Pregnane X receptor (PXR), constitutive androstane receptor (CAR), and benzoate $\mathrm{X}$ receptor (BXR) define three pharmacologically distinct classes of nuclear receptors. Mol. Endocrinol. 16, 977-986. doi: 10.1210/mend. 16.5.0828

Moraes, J. S., da Silva Nornberg, B. F., Castro, M. R., de, Vaz, B., dos, S., Mizuschima, C. W., et al. (2020). Zebrafish (Danio rerio) ability to activate $\mathrm{ABCC}$ transporters after exposure to glyphosate and its formulation Roundup Transorb ${ }^{\circledR}$. Chemosphere 248:125959. doi: 10.1016/j.chemosphere. 2020.125959

Mottaz, H., Schönenberger, R., Fischer, S., Eggen, R. I. L., Schirmer, K., and Groh, K. J. (2017). Dose-dependent effects of morphine on lipopolysaccharide (LPS)induced inflammation, and involvement of multixenobiotic resistance (MXR) transporters in LPS efflux in teleost fish. Environ. Poll. 221, 105-115.

Mottino, A. D., Hoffman, T., Jennes, L., and Vore, M. (2000). Expression and localization of multidrug resistant protein mrp2 in rat small intestine. J. Pharmacol. Exp. Ther. 293, 717-723.

Müller, J., Keiser, M., Drozdzik, M., and Oswald, S. (2016). Expression, regulation and function of intestinal drug transporters: An update. Biol. Chem. 398, 175-192. doi: 10.1515/hsz-2016-0259

Navarro-Quiles, C., Mateo-Bonmatí, E., and Micol, J. L. (2018). ABCE proteins: From molecules to development. Front. Plant Sci. 9:1125. doi: 10.3389/fpls. 2018.01125

Nayagam, J. S., Williamson, C., Joshi, D., and Thompson, R. J. (2020). Review article: liver disease in adults with variants in the cholestasis-related genes ABCB11. ABCB4 and ATP8B1. Aliment. Pharmacol. Ther. 52, 1628-1639. doi: 10.1111/apt.16118

Neudeck, B. L., Loeb, J. M., Faith, N. G., and Czuprynski, C. J. (2004). Intestinal $\mathrm{P}$ glycoprotein acts as a natural defense mechanism against Listeria monocytogenes. Infect. Immun. 72, 3849-3854. doi: 10.1128/IAI.72.7.38493854.2004

Neuman, R. I., van Kalmthout, J. A. M., Pfau, D. J., Menendez, D. M., Young, L. H., and Forrest, J. N. (2018). AMP-activated protein kinase and adenosine are both metabolic modulators that regulate chloride secretion in the shark rectal gland (Squalus acanthias). Am. J. Physiol. Cell Physiol. 314, C473-C482. doi: 10.1152/ajpcell.00171.2017

Paetzold, C. S., Ross, N. W., Richards, R. C., Jones, M., Hellou, J., and Bard, S. M. (2009). Up-regulation of hepatic ABCC2, ABCG2, CYP1A1 and GST in multixenobiotic-resistant killifish (Fundulus heteroclitus) from the Sydney Tar Ponds, Nova Scotia, Canada. Mar. Environ. Res. 68, 37-47. doi: 10.1016/j. marenvres.2009.04.002

Painefilú, J. (2021). Toxicidad de Cianotoxinas Presentes en Cuerpos de Agua Dulce de Norpatagonia en la Trucha Arcoíris, Oncorhynchus Mykiss. San Carlos de Bariloche: Universidad Nacional del Comahue.

Painefilú, J. C., Bianchi, V. A., Krock, B., De Anna, J. S., Kristoff, G., and Luquet, C. M. (2020). Effects of paralytic shellfish toxins on the middle intestine of Oncorhynchus mykiss: Glutathione metabolism, oxidative status, lysosomal function and ATP-binding cassette class C (ABCC) proteins activity. Ecotoxicol. Environ. Saf. 204:111069. doi: 10.1016/j.ecoenv.2020.111069

Painefilú, J. C., Pascual, M. M., Bieczynski, F., Laspoumaderes, C., González, C., Villanueva, S. S. M., et al. (2019). Ex vivo and in vivo effects of arsenite on GST and $\mathrm{ABCC} 2$ activity and expression in the middle intestine of the rainbow trout Oncorhynchus mykiss. Comp. Biochem. Physiol. C Toxicol. Pharmacol. 225, 1-8. doi: 10.1016/j.cbpc.2019.108566

Parreira, B., Cardoso, J. C. R., Costa, R., Couto, A. R., Bruges-Armas, J., and Power, D. M. (2018). Persistence of the ABCC6 genes and the emergence of the bony skeleton in vertebrates. Sci. Rep. 8:6027. doi: 10.1038/s41598-018-24370-7

Pflugmacher, S., Wiegand, C., Oberemm, A., Beattie, K. A., Krause, E., Codd, G. A., et al. (1998). Identification of an enzymatically formed glutathione conjugate of the cyanobacterial hepatotoxin microcystin-LR: The first step of detoxication. 
Biochim. Biophys. Acta Gen. Subj. 1425, 527-533. doi: 10.1016/S0304-4165(98) 00107-X

Pires, L. M. D., Karlsson, K. M., Meriluoto, J. A. O., Kardinaal, E., Visser, P. M., Siewertsen, K., et al. (2004). Assimilation and depuration of microcystin-LR by the zebra mussel, Dreissena polymorpha. Aquat. Toxicol. 69, 385-396. doi: 10.1016/j.aquatox.2004.06.004

Popovic, M., Zaja, R., Loncar, J., and Smital, T. (2010). A novel ABC transporter: The first insight into zebrafish (Danio rerio) ABCH1. Mar. Environ. Res. 69, S11-S13. doi: 10.1016/j.marenvres.2009.10.016

Quezada, C., Alarcón, S., Cárcamo, J. G., Yáñez, A., Casanello, P., Sobrevia, L., et al. (2011). Increased expression of the multidrug resistance-associated protein 1 (MRP1) in kidney glomeruli of streptozotocin-induced diabetic rats. Biol. Chem. 392, 529-537. doi: 10.1515/BC.2011.052

Rakvács, Z., Kucsma, N., Gera, M., Igriczi, B., Kiss, K., Barna, J., et al. (2019). The human ABCB6 protein is the functional homologue of HMT-1 proteins mediating cadmium detoxification. Cell. Mol. Life Sci. 76, 4131-4144. doi: 10. 1007/s00018-019-03105-5

Ramos, P., Schmitz, M., Gama, S., Portantiolo, A., Durruthy, M. G., de Souza Votto, A. P., et al. (2018). Cytoprotection of lipoic acid against toxicity induced by saxitoxin in hippocampal cell line HT-22 through in silico modeling and in vitro assays. Toxicology 393, 171-184. doi: 10.1016/j.tox.2017.11.004

Ratner, M. A., Decker, S. E., Aller, S. G., Weber, G., and Forrest, J. R. J. N. (2006). Mercury toxicity in the shark (Squalus acanthias) rectal gland: Apical CFTR chloride channels are inhibited by mercuric chloride. J. Exp. Zool. 305, 259-267. doi: $10.1002 /$ jez.a.257

Reichel, V., Miller, D. S., and Fricker, G. (2008). Texas Red transport across rat and dogfish shark (Squalus acanthias) choroid plexus. Am. J. Physiol. Regul. Integr. Comp. Physiol. 295, 1311-1319. doi: 10.1152/ajpregu.90373.2008

Ren, J., Chung-Davidson, Y. W., Yeh, C. Y., Scott, C., Brown, T., and Li, W. (2015). Genome-wide analysis of the ATP-binding cassette (ABC) transporter gene family in sea lamprey and Japanese lamprey. BMC Genomics 16:436. doi: 10.1186/s12864-015-1677-z

Reschly, E. J., Bainy, A. C. D., Mattos, J. J., Hagey, L. R., Bahary, N., Mada, S. R., et al. (2007). Functional evolution of the vitamin $\mathrm{D}$ and pregnane $\mathrm{X}$ receptors. BMC Evol. Biol. 7:222. doi: 10.1186/1471-2148-7-222

Robey, R. W., Robinson, A. N., Ali-Rahmani, F., Huff, L. M., Lusvarghi, S., Vahedi, S., et al. (2021). Characterization and tissue localization of zebrafish homologs of the human ABCB1 multidrug transporter. bioRxiv doi: 10.1101/2021.02.18. 431829

Roninson, I. B., Herbert, T. A., Housman, D. E., Howell, N., and Varshavsky, A. (1984). Amplification of specific DNA sequences correlates with multi-drug resistance in Chinese hamster cells. Nature 309, 626-628.

Ruhr, I. M., Bodinier, C., Mager, E. M., Esbaugh, A. J., Williams, C., Takei, Y., et al. (2014). Guanylin peptides regulate electrolyte and fluid transport in the Gulf toadfish (Opsanus beta) posterior intestine. Am. J. Physiol. Regul. Integr. Comp. Physiol. 307, R1167-R1179. doi: 10.1152/ajpregu.00188.2014

Ruhr, I. M., Mager, E. M., Takei, Y., and Grosell, M. (2015). The differential role of renoguanylin in osmoregulation and apical $\mathrm{Cl}-/ \mathrm{HCO}-3$ exchange activity in the posterior intestine of the gulf toadfish (Opsanus beta). Am. J. Physiol. Regul. Integr. Comp. Physiol. 309, R399-R409. doi: 10.1152/ajpregu.00118. 2015

Ruhr, I. M., Schauer, K. L., Takei, Y., and Grosell, M. (2018). Renoguanylin stimulates apical CFTR translocation and decreases $\mathrm{HCO} 3$-secretion through PKA activity in the Gulf toadfish (Opsanus beta). J. Exp. Biol. 221:jeb173948. doi: $10.1242 /$ jeb. 173948

Ruhr, I. M., Takei, Y., and Grosell, M. (2016). The role of the rectum in osmoregulation and the potential effect of renoguanylin on SLC26a6 transport activity in the Gulf toadfish (Opsanus beta). Am. J. Physiol. Regul. Integr. Comp. Physiol. 311, R179-R191. doi: 10.1152/ajpregu.00033.2016

Rust, M. B. (2003). "Nutritional Physiology" in Fish Nutrition. eds J. E. Halver and R. W. Hardy (San Diego: Academic Press). 367-452.

Sabri, D., Rabie, T., Ahmed, A., Zakaria, S., and Bourdineaud, J.-P. (2012). Heavy Metals-Induced Expression of ABCB10 Gene in Zebrafish Danio rerio. Egypt. Acad. J. Biol. Sci. C, Physiol. Mol. Biol. 4, 97-106. doi: 10.21608/eajbsc.2012. 16128

Schatton, T., Yang, J., Kleffel, S., Uehara, M., Barthel, S. R., Schlapbach, C., et al. (2015). ABCB5 Identifies Immunoregulatory Dermal Cells. Cell Rep. 12, 1564-1574. doi: 10.1016/j.celrep.2015.08.010
Seguin, A., Takahashi-Makise, N., Yien, Y. Y., Huston, N. C., Whitman, J. C., Musso, G., et al. (2017). Reductions in the mitochondrial ABC transporter Abcb10 affect the transcriptional profile of heme biosynthesis genes. J. Biol. Chem. 292, 16284-16299. doi: 10.1074/jbc.M117.797415

Shaw, J. R., Jackson, B., Gabor, K., Stanton, S., Hamilton, J. W., and Stanton, B. A. (2007). The influence of exposure history on arsenic accumulation and toxicity in the k. Environ. Toxicol. Chem. 26, 2704-2709. doi: 10.1897/07-032.1

Singer, T. D., Tucker, S. J., Marshall, W. S., and Higgins, C. F. (1998). A divergent CFTR homologue: Highly regulated salt transport in the euryhaline teleost F. heteroclitus. Am. J. Physiol. Cell Physiol. 274, 715-723. doi: 10.1152/ajpcell.1998. 274.3.c715

Singhal, R. K., Anderson, M. E., and Meister, A. (1987). Glutathione, a first line of defense against cadmium toxicity. FASEB J. 1, 220-223. doi: 10.1096/fasebj.1.3. 2887478

Slot, A. J., Molinski, S. V., and Cole, S. P. C. (2011). Mammalian multidrugresistance proteins (MRPs). Essays Biochem. 50, 179-207. doi: 10.1042/ BSE0500179

Stahl, M., Stahl, K., Brubacher, M. B., and Forrest, J. N. (2012). Divergent CFTR orthologs respond differently to the channel inhibitors CFTR inh-172, glibenclamide, and GlyH-101]. Am. J. Physiol. Cell Physiol. 302, 67-76. doi: 10.1152/ajpcell.00225.2011

Stolarczyk, E. I, Reiling, C. J., and Paumi, C. M. (2011). Regulation of ABC Transporter Function Via Phosphorylation by Protein Kinases. Curr. Pharm. Biotechnol. 12, 621-635. doi: 10.2174/138920111795164075

Strachan, L. R., Stevenson, T. J., Freshner, B., Keefe, M. D., Bowles, M. D., and Bonkowsky, J. L. (2017). A zebrafish model of X-linked adrenoleukodystrophy recapitulates key disease features and demostrates a developmental requirement for abcd 1 in oligodendrocyte patterning and myelination. Hum. Mol. Genet. 26, 3600-3614. doi: $10.1093 / \mathrm{hmg} / \mathrm{ddx} 249$

Sturm, A., and Segner, H. (2005). P-glycoprotein and xenobiotic efflux transport in fish. Biochem. Mol. Biol. Fishes 6, 495-533.

Sturm, A., Cunningham, P., and Dean, M. (2009). The ABC transporter gene family of Daphnia pulex. BMC Genomics 10:170. doi: 10.1186/1471-2164-10-170

Sun, J., She, P., Liu, X., Gao, B., Jin, D., and Zhong, T. P. (2021). Disruption of abcc6 transporter in zebrafish causes ocular calcification and cardiac fibrosis. Int. J. Mol. Sci. 22, 1-18. doi: 10.3390/ijms22010278

Szakacs, G., and Abele, R. (2020). An inventory of lysosomal ABC transporters. FEBS Lett. 594, 3965-3985. doi: 10.1002/1873-3468.13967

Szeri, F., Corradi, V., Niaziorimi, F., Donnelly, S., Conseil, G., Cole, S. P. C., et al. (2021). Mutagenic analysis of the putative abcc6 substrate-binding cavity using a new homology model. Int. J. Mol. Sci. 22:6910. doi: 10.3390/ijms22136910

Takei, Y., and Yuge, S. (2007). The intestinal guanylin system and seawater adaptation in eels. Gen. Comp. Endocrinol. 152, 339-351. doi: 10.1016/j.ygcen. 2007.05.005

Tam, S.-P., Mok, L., Chimini, G., Vasa, M., and Deeley, R. G. (2006). ABCA1 mediates high-affinity uptake of 25 -hydroxycholesterol by membrane vesicles and rapid efflux of oxysterol by intact cells. Am. J. Physiol. Cell Physiol. 291, 490-502. doi: 10.1152/ajpcell.00055.2006

Tawbeh, A., Gondcaille, C., Trompier, D., and Savary, S. (2021). Peroxisomal abc transporters: An update. Int. J. Mol. Sci. 22:6093. doi: 10.3390/ijms22116093

Telles, C. J., Decker, S. E., Motley, W. W., Peters, A. W., Mehr, A. P., Frizzel, R. A., et al. (2016). Functional and molecular identification of a TASK-1 potassium channel regulating chloride secretion through CFTR channels in the shark rectal gland: Implications for cystic fibrosis. Am. J. Physiol. Cell Physiol. 311, C884-C894. doi: 10.1152/ajpcell.00030.2016

Tencalla, F. G., Dietrich, D. R., and Schlatter, C. (1994). Toxicity of Microcystis aeruginosa peptide toxin to yearling rainbow trout (Oncorhynchus mykiss). Aquat. Toxicol. 30, 215-224. doi: 10.1016/0166-445X(94)90059-0

Thomas, C., Aller, S. G., Beis, K., Carpenter, E. P., Chang, G., Chen, L., et al. (2020). Structural and functional diversity calls for a new classification of $A B C$ transporters. FEBS Lett. 594, 3767-3775. doi: 10.1002/1873-3468.13935

Torres, R., Pizarro, L., Csendes, A., García, C., and Lagos, N. (2007). GTX 2/3 epimers permeate the intestine through a paracellular pathway. J. Toxicol. Sci. 32, 241-248. doi: 10.2131/jts.32.241

Tutundjian, R., Cachot, J., Leboulenger, F., and Minier, C. (2002). Genetic and immunological characterisation of a multixenobiotic resistance system in the turbot (Scophthalmus maximus). Comp. Biochem. Physiol. B Biochem. Mol. Biol. 132, 463-471. doi: 10.1016/S1096-4959(02)00058-1 
Uinuk-Ool, T. S., Mayer, W. E., Sato, A., Takezaki, N., Benyon, L., Cooper, M. D., et al. (2003). Identification and characterization of a TAP-family gene in the lamprey. Immunogenetics 55, 38-48. doi: 10.1007/s00251-003-0548-y

Umans, R. A., and Taylor, M. R. (2012). Zebrafish as a model to study drug transporters at the bloodbrain barrier. Clin. Pharmacol. Ther. 92, 567-570. doi: 10.1038/clpt.2012.168

Van Aubel, R. A. M. H., Smeets, P. H. E., Peters, J. G. P., Bindels, R. J. M., and Russel, F. G. M. (2002). The MRP4/ABCC4 gene encodes a novel apical organic anion transporter in human kidney proximal tubules: Putative efflux pump for urinary cAMP and cGMP. J. Am. Soc. Nephrol. 13, 595-603. doi: 10.1681/asn.v133595

Venkateswaran, A., Laffitte, B. A., Joseph, S. B., Mak, P. A., Wilpitz, D. C., Edwards, P. A., et al. (2000). Control of cellular cholesterol efflux by the nuclear oxysterol receptor LXRa. Proc. Natl. Acad. Sci. 97, 12097-12102.

Verdile, N., Pasquariello, R., Scolari, M., Scirè, G., Brevini, T. A. L., and Gandolfi, F. (2020). A detailed study of rainbow trout (Onchorhynchus mykiss) intestine revealed that digestive and absorptive functions are not linearly distributed along its length. Animals 10:745. doi: 10.3390/ani10040745

Verrier, P. J., Bird, D., Burla, B., Dassa, E., Forestier, C., Geisler, M., et al. (2008). Plant ABC proteins - a unified nomenclature and updated inventory. Trends Plant Sci. 13, 151-159. doi: 10.1016/j.tplants.2008.02.001

Wachnowsky, C., Fidai, I., and Cowan, J. A. (2018). Iron-sulfur cluster biosynthesis and trafficking - Impact on human disease conditions. Metallomics 10, 9-29. doi: 10.1039/c7mt00180k

Wambach, J. A., Yang, P., Wegner, D. J., Heins, H. B., Luke, C., Li, F., et al. (2020). Functional genomics of ABCA3 variants. Am. J. Respir. Cell Mol. Biol. 63, 436-443. doi: 10.1165/rcmb.2020-0034MA

Wang, X., and Wang, W. X. (2016). Homeostatic regulation of copper in a marine fish simulated by a physiologically based pharmacokinetic model. Environ. Pollut. 218, 1245-1254. doi: 10.1016/j.envpol.2016.08.080

Weber, G. J., Mehr, A. P., Sirota, J. C., Aller, S. G., Decker, S. E., Dawson, D. C., et al. (2006). Mercury and zinc differentially inhibit shark and human CFTR orthologues: Involvement of shark cysteine 102. Am. J. Physiol. Cell Physiol. 290, 793-801. doi: 10.1152/ajpcell.00203.2005

Wetherbee, B. M., and Cortés, E. (2004). "Food Consumption and Feeding Habits" in Biology Of Sharks And Their Relatives. eds J. C. Carrier, J. A. Musick, and M. R. Heithaus (Boca Raton: CRC Press), 225-246.

Wiegand, C., and Pflugmacher, S. (2005). Ecotoxicological effects of selected cyanobacterial secondary metabolites a short review. Toxicol. Appl. Pharmacol. 203, 201-218. doi: 10.1016/j.taap.2004.11.002

Wiese, M., D’Agostino, P. M., Mihali, T. K., Moffitt, M. C., and Neilan, B. A. (2010). Neurotoxic alkaloids: Saxitoxin and its analogs. Mar. Drugs 8, 2185-2211. doi: 10.3390/md8072185

Wilson, J. M., and Castro, L. F. C. (2011). "Morphological Diversity of the Gastrointestinal Tract in Fishes" in The Multifunctional Gut Of Fish. eds M. Grosell, A. P. Farrel, and C. J. Brauner (London: Academic Press). 136-165.

Wong, M. K. S., Pipil, S., Kato, A., and Takei, Y. (2016). Duplicated CFTR isoforms in eels diverged in regulatory structures and osmoregulatory functions. Comp. Biochem. Physiol. art A Mol. Integr. Physiol. 199, 130-141. doi: 10.1016/j.cbpa. 2016.06.018

Wu, B., Wu, X., Liu, S., Wang, Z., and Chen, L. (2019). Size-dependent effects of polystyrene microplastics on cytotoxicity and efflux pump inhibition in human Caco-2 cells. Chemosphere. 221, 333-341. doi: 10.1016/j.chemosphere.2019.01. 056

Xie, L., Xie, P., Guo, L., Li, L., Miyabara, Y., and Park, H. D. (2005). Organ distribution and bioaccumulation of microcystins in freshwater fish at different trophic levels from the eutrophic Lake Chaohu. China. Environ. Toxicol. 20, 293-300. doi: 10.1002/tox.20120

Xie, L., Xie, P., Ozawa, K., Honma, T., Yokoyama, A., and Park, H. D. (2004). Dynamics of microcystins-LR and -RR in the phytoplanktivorous silver carp in a sub-chronic toxicity experiment. Environ. Pollut. 127, 431-439. doi: 10.1016/ j.envpol.2003.08.011

Yuan, L., Lv, B., Zha, J., and Wang, Z. (2014). Transcriptional expression analysis of ABC efflux transporters and xenobiotic-metabolizing enzymes in the Chinese rare minnow. Environ. Toxicol. Pharmacol. 37, 984-995. doi: 10.1016/j.etap. 2014.03.015

Zaja, R., Lončar, J., Popović, M., and Smital, T. (2011). First characterization of fish P-glycoprotein (abcb1) substrate specificity using determinations of its ATPase activity and calcein-AM assay withPLHC-1/dox cell line. Aquat. Tox. 103, 53-62. doi: 10.1016/j.aquatox.2011.02.005

Zaja, R., Munić, V., Sauerborn Klobucar, R., Ambriovic-Ristov, A., and Smital, T. (2008). Cloning and molecular characterization of apical efflux transporters ( $\mathrm{ABCB} 1, \mathrm{ABCB} 11$ and $\mathrm{ABCC} 2$ ) in rainbow trout (Oncorhynchus mykiss) hepatocytes. Aquat. Tox. 90, 322-332. doi: 10.1016/j.aquatox.2008.09.012

Zaja, R., Popović, M., Lončar, J., and Smital, T. (2016). Functional characterization of rainbow trout (Oncorhynchus mykiss) Abcg2a (Bcrp) transporter. Comp. Biochem. Physiol. C Toxicol. Pharmacol. 190, 15-23. doi: 10.1016/j.cbpc.2016. 07.005

Zaja, R., Sauerborn Klobucar, R., and Smital, T. (2007). Detection and functional characterization of Pgp1 (ABCB1) and MRP3 (ABCC3) efflux transporters in the PLHC-1 fish hepatoma cell line. Aquat. Tox. 81, 365-376. doi: 10.1016/j. aquatox.2006.12.015

ZFIN Zebrafish Nomenclature Conventions (2019). Available online at: https://zfin.atlassian.net/wiki/spaces/general/pages/1818394635/ZFIN+ Zebrafish+Nomenclature+Conventions [Accessed October 07, 2021].

Zhang, C., Miki, T., Shibasaki, T., Yokokura, M., Saraya, A., and Seino, S. (2006). Identification and characterization of a novel member of the ATP-sensitive K+ channel subunit family, Kir6.3, in zebrafish. Physiol. Genomics 24, 290-297. doi: 10.1152/physiolgenomics.00228.2005

Zhang, L., Fang, Y., Lu, X., Xu, S., Cai, F., Yu, M., et al. (2020). Transcriptional response of zebrafish larvae exposed to lindane reveals two detoxification genes of ABC transporter family (abcg5 and abcg8). Comp. Biochem. Physiol. C Toxicol. Pharmacol. 232:108755. doi: 10.1016/j.cbpc.2020.108755

Zhang, Q. L., Dong, Z. X., Luo, Z. W., Zhang, M., Deng, X. Y., Guo, J., et al. (2020). The Impact of Mercury on the Genome-Wide Transcription Profile of Zebrafish Intestine. Netherlands: Elsevier. doi: 10.1016/j.jhazmat.2019.121842

Zhu, T., Corraze, G., Plagnes-Juan, E., Quillet, E., Dupont-Nivet, M., and Skiba-Cassy, S. (2018). Regulation of genes related to cholesterol metabolism in rainbow trout (Oncorhynchus mykiss) fed plant-based diet. Am. J. Physiol. Regul. Integr. Comp. Physiol. 314, 58-70. doi: 10.1152/ajpregu.00179. 2017

Conflict of Interest: The authors declare that the research was conducted in the absence of any commercial or financial relationships that could be construed as a potential conflict of interest.

Publisher's Note: All claims expressed in this article are solely those of the authors and do not necessarily represent those of their affiliated organizations, or those of the publisher, the editors and the reviewers. Any product that may be evaluated in this article, or claim that may be made by its manufacturer, is not guaranteed or endorsed by the publisher.

Copyright (c) 2021 Bieczynski, Painefilu, Venturino and Luquet. This is an openaccess article distributed under the terms of the Creative Commons Attribution License (CC BY). The use, distribution or reproduction in other forums is permitted, provided the original author(s) and the copyright owner(s) are credited and that the original publication in this journal is cited, in accordance with accepted academic practice. No use, distribution or reproduction is permitted which does not comply with these terms. 